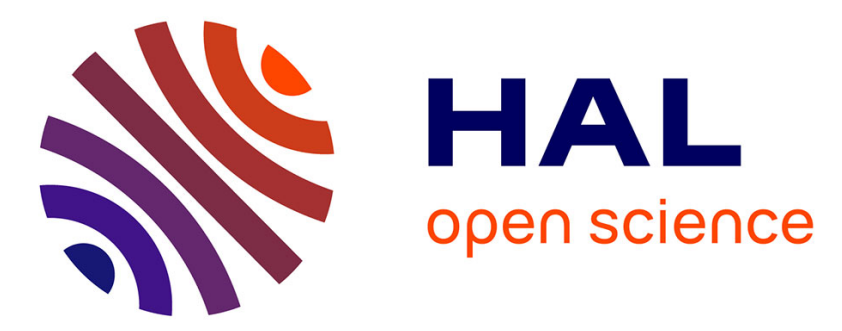

\title{
Comparison of embryonic and adult shells of Sepia officinalis (Cephalopoda, Mollusca)
}

Yannicke Dauphin, Gilles Luquet, Aline Percot, Laure Bonnaud-Ponticelli

\section{To cite this version:}

Yannicke Dauphin, Gilles Luquet, Aline Percot, Laure Bonnaud-Ponticelli. Comparison of embryonic and adult shells of Sepia officinalis (Cephalopoda, Mollusca). Zoomorphology, 2020, 139 (2), pp.151169. 10.1007/s00435-020-00477-2 . hal-02557254

\section{HAL Id: hal-02557254 \\ https://hal.science/hal-02557254}

Submitted on 28 Apr 2020

HAL is a multi-disciplinary open access archive for the deposit and dissemination of scientific research documents, whether they are published or not. The documents may come from teaching and research institutions in France or abroad, or from public or private research centers.
L'archive ouverte pluridisciplinaire HAL, est destinée au dépôt et à la diffusion de documents scientifiques de niveau recherche, publiés ou non, émanant des établissements d'enseignement et de recherche français ou étrangers, des laboratoires publics ou privés. 


\title{
Comparison of embryonic and adult shells of Sepia officinalis (Cephalopoda, Mollusca)
}

\author{
Yannicke Dauphin ${ }^{1, *}$, Gilles Luquet ${ }^{2}$, Aline Percot $^{3}$, Laure Bonnaud-Ponticelli2,* \\ ${ }^{1}$ Institut de Systématique, Evolution, Biodiversité, UMR 7205 CNRS, Sorbonne Université, \\ EPHE, Muséum National d'Histoire Naturelle, Paris, France \& Department of Biomaterials, \\ Max-Planck-Institute of Colloids and Interfaces, Potsdam, Germany \\ ${ }^{2}$ Biologie des Organismes et Ecosystèmes Aquatiques, UMR CNRS 7208, Sorbonne Université, \\ IRD 207, UCN, UA, Muséum National d'Histoire Naturelle, Paris, France \\ ${ }^{3}$ De la Molécule aux Nano-Objets: Réactivité, Interactions et Spectroscopies, UMR 8233 CNRS, \\ Sorbonne Université, Paris, France \\ *Corresponding authors \\ Yannicke Dauphin, yannicke.dauphin@upmc.fr, ORCID: 0000-0003-2870-8409 \\ Laure Bonnaud-Ponticelli, laure.bonnaud@mnhn.fr, ORCID: 0000-0001-7510-5032
}

\begin{abstract}
Development and evolution of the shell in cephalopods is difficult to establish as there is few species with a calcified shell that could be fossilized (stable in geological time). Internal cuttlebone of sepiids is so particular that homologies are difficult to find. The developmental sequence in embryos give some response elements by comparison with adult cuttlebone. The macro and microstructure of adult shell is well known but an approach at nanostructural level allows to determine structure and composition of the two main parts, the dorsal shield and chambered part. We evidence in the embryonic shell, mainly organic, a light calcification of the shell, which occurs directly as aragonite, as it is all along the formation of the shell and whatever the parts. In embryonic shell, the prismatic and/or lamellar layers, present in adult, are not differentiated and the dorsal shield grows progressively, from posterior to anterior. Despite microstructural differences, all layers of both chambered part and dorsal shield are composed of rounded nanogranules (between 50 and $100 \mathrm{~nm}$ ), similar to what is found in other mollusc shells. Finally, the presence of pillars evidenced in embryo suggests either that their absence in extinct
\end{abstract}


lineages of sepiids is the result of a diagenetic process or that they are a novelty in present sepiid
species.

Keywords Sepia - embryonic shell - structure - composition

\section{Introduction}

Mollusks are a major group of marine organisms. Among them, cephalopods received a peculiar attention in different fields of research. They are able to synthesize inner or outer shells and are consequently of interest in biomineralization (Mutvei 1964; Dauphin 1979, 1981; Lowenstam and Weiner 1989; Bandel 1990; Marie et al. 2009; Cuif et al. 2013; Checa et al. 2015; Le Pabic et al. 2016) as well as from an evolutionary point of view (Haas 2003; Kröger et al. 2011; Allcock et al. 2015). Known since the Paleozoic era, they are used in palaeontology as good stratigraphic markers because of calcified shells, fast evolution and large dispersion of major extinct species. Only three extant cephalopod genera are able to build a calcified shell: external in Nautilus, internal in Spirula and Sepia. For this particularity, they are used in biomimetic and biomedical research (Ogasawara et al. 2000; Kim et al. 2012; Karthika et al. 2016). Recently, calcified processes have been studied in the context of global change and ocean acidification (Gutowska et al. 2008; Dorey et al. 2013; Sigwart et al. 2015).

Sepia officinalis Linnaeus, 1758 and Sepia pharaonis Ehrenberg, 1931 are the most studied species, notably because of their abundance and commercial interest as seafood (Bettencourt and Guerra 2001; Sykes et al. 2014).

One of the first detailed microstructural analyses of the shell and the living tissues of Sepia officinalis was that of Appellöf (1893). The proostracum (dorsal shield component), the ventral part with pillars and lamellae, the fork, the siphonal tube and the rostrum were identified by Naef (1922). The continuity of the layers in dorsal shield and rostrum was described, as well as the presence of chitin (Appellöf 1893; Naef 1922). Numerous comparative studies have been done to establish homologies of the different parts of the shell of present versus fossil coleoids. In his comprehensive work on the structure and mineralogy of mollusc shells, Boggild (1930) noted that the dorsal shield is composed of three layers, the median layer being fully organic in 
the layers of Sepia are aragonitic, the dorsal shield and the rostrum being prismatic. As other cephalopod shells, the aragonite has a low Sr content (Dauphin et al. 2007; Florek et al. 2009). The structure of the chambered part and the labyrinthine ("meanderlike") organization of the pillars/walls were also described and illustrated. Barskov (1973) used SEM to observe the minute structure of the cuttlebone and described the microstructure of the septa. A comparison of some Sepia species has shown that despite differences in the morphology of the cuttlebone, their arrangements and microstructures are similar (Dauphin 1981). The regular layered structure of the septa of Spirula was described by Grégoire $(1961,1967)$, who called it "nacre" despite the absence of tablets. The same structure was also called "lamellar fibrillar structure" (Erben 1972) or "type II nacre" (Mutvei 1970), then lamello-fibrillar nacre (Mutvei 2016). Such a structure was also found in Sepia (Dauphin and Keller 1982; Doguzhaeva and Dunca 2015).

Recently an analysis of the cuttlebone using for the first time CT-scan has drawn a dynamic 3D image of the development and growth of the shell from embryo to adult (Le Pabic et al. 2019).

Most studies dealing with the microstructure and composition of the cuttlebones were performed on adult samples. For example, the presence of chitin and proteins in the adult cuttlebone has been shown by Degens et al. (1967), Drozdova et al. (1971), Hunt and Nixon (1981).

The first studies on embryonic shell of S. officinalis and S. pharaonis were done by Bandel and Boletzky (1979), then detailed by Sen (2013) and Le Pabic et al. (2016, 2019), but the microstructures and compositions of the calcified parts of Sepia embryonic shells remained to be more accurately characterized.

In this study, we therefore examined the microstructures and nanostructures of the calcified parts of Sepia officinalis embryonic shells, with some data on their composition, in comparison to the adult cuttlebone and other mineralized structures synthesized by mollusks. In addition to the understanding of variation in building the shell during development and growth of animal, our study brings new information on shell evolution within mollusks. 


\section{Material and methods}

\section{Materials}

Sepia officinalis adult shells were collected on beaches in Normandy (France). The maximal length of the cuttlebones was $30 \mathrm{~cm}$.

S. officinalis eggs were collected in Luc-sur-Mer (Normandie, France) and kept in the lab in artificial sea water (salinity: $35 \mathrm{ppt}$ - closed circulatory system), at $18^{\circ} \mathrm{C}$. Eggs were opened and the embryos (whose stage is determined by morphological characteristics) were immerged in sea-water with 5\% Ethanol, following recommendations of Buttler-Struben et al. (2018) and Winlow et al. (2018) and according to directive 2010-63-UE and French decree 2013-118. Cuttlebones were obtained by dissection. All soft tissues were removed and the cuttlebones were kept dried.

Naef (1922, 1928a, 1928b) has divided the embryonic period into stages, specified later by Lemaire (1970) and Boletzky et al. (2016). We used the Lemaire and Boletzky et al. staging in this study. Stages from the beginning of matrix shell formation (stage 24), beginning of mineralisation (and first chamber, stage 25) to early final stage 30 (6 to 8 chambers) were analysed.

Crab chitin (Sigma Aldrich) and Bovine serum albumin (BSA, Eurobio) were used as references for the organic components. A marine non biogenic aragonite (botryoidal aragonite) was selected as a mineral reference.

\section{Scanning electron microscopy (SEM)}

A Philips XL30 and a Zeiss Gemini LEO 1550 were used on coated samples. Secondary electron images are indicated as SE-SEM in the legends. A FEI FESEM Quanta F600 and a Phenom Pro $\mathrm{X}$ were used for images in back scattered electron mode (BSE-SEM). In this technique, imaging contrast depends on the atomic number of the atoms composing the substrate material: the organic structures appear in black, in contrast to the mineral units with heavier chemical elements $(\mathrm{Ca}, \mathrm{Sr})$. The sample does not need to be covered by a conductive layer, so that the same sample can be used for SEM and AFM observations.

Fractured shells and polished samples were observed. Samples embedded in resin were 
polished using various grades of diamond paste down to a final $0.25 \mathrm{~mm}$ grade. The polished surfaces were then cleaned with a detergent mixed with hot water for 1 min under ultrasonication to remove any oil residue from the pastes and rinsed with water. Then, according to the technique subsequently employed, additional preparative procedures were undertaken, the details of which are given in the figure captions.

Figure S1 displays the used terminology for the orientation of the sections.

\section{Atomic Force Microscopy (AFM)}

Samples were studied using a Nanoscope IIIa multi-mode scanning probe microscope operating in tapping mode. The tapping mode AFM utilizes an oscillating tip with amplitude of approximately several tens of $\mathrm{nm}$ when the tip is not in contact with the surface. The resolution of tapping mode AFM is in the order of a few nm. Phase imaging is a powerful extension to detect variations in chemical composition, friction and other physical properties. The AFM sensor oscillates over the surface sample, and the amplitude of the oscillation is used to control the scanner. An image can be formed from this amplitude signal that emphasizes the details of the sample surface.

Compared with conventional secondary electron imaging SEM (SE-SEM), AFM provides topographic direct height measurements and views of surface features since no coating is necessary. Moreover, three-dimensional nanoscale resolution AFM images are obtained without the time-consuming sample preparation (e.g. decalcification, thinning...) required for similar resolution Transmission Electron Microscopy examination.

\section{Fourier Transform Infrared Spectrometry (FTIR)}

All spectra were recorded at $4 \mathrm{~cm}^{-1}$ resolution with 16 scans on a Perkin-Elmer Frontier Fourier transform infrared spectrometer (FTIR), in the wavenumber range 4000 to $450 \mathrm{~cm}^{-1}$. The spectrometer was equipped with a Diffuse Reflectance accessory, which permits DRIFT measurements with high sensitivity on powders. All spectra were corrected by the KubelkaMunk function. A background spectrum was measured for pure KBr. Sample spectra were automatically ratioed against background to minimize $\mathrm{CO}_{2}$ and $\mathrm{H}_{2} \mathrm{O}$ bands. Correlation 
coefficients between two spectra of the same samples were about $99 \%$. The dorsal shield and the ventral zone were mechanically separated in adult samples, immersed in $3 \% \mathrm{NaClO}$ for $1 \mathrm{~h}$ to remove organic contaminants, rinsed with Milli-Q water, dried, and ground into powder.

\section{Micro-Raman spectroscopy}

The Raman spectra were recorded with a LabRam HR 800 spectrometer (Horiba Jobin Yvon) equipped with a Peltier cooled CCD detector and using the $514 \mathrm{~nm}$ line of a water-cooled Ar+ laser (Innova 90C, Coherent Inc.). Raman scattering is collected via a microscope (Olympus) equipped with a 50x long working distance objective, allowing a laser spot size of about $5 \mu \mathrm{m}$. The laser power at the sample is between 2 and $3 \mathrm{~mW}$. The spectrometer is equipped with a 600 lines/mm grating and allowing a $2 \mathrm{~cm}^{-1}$ spectral resolution on the range $100-1700 \mathrm{~cm}^{-1}$. Calibration has been checked with respect to the $520.7 \mathrm{~cm}^{-1}$ band of silicon. Typical recording times consist of 3 accumulations of $10 \mathrm{~s}$.

\section{Calcein labelling}

Stage 25/26 and 30 embryos were incubated in vitro in calcein-containing seawater (30 mg/L; CNAM, Sigma) during $24 \mathrm{~h}$ followed by $48 \mathrm{~h}$ incubation in seawater without dye. Then shells were removed from frozen embryos and observed using a Leica DM-IRB microscope.

\section{Results}

\section{Morphology - terminology}

The descriptive terminology of the cuttlebone and the comparisons with external shells differ according to the authors. Here, we used the main terms defined by Barskov (1973). The adult cuttlebone is divided into two main parts: the compact dorsal shield and the porous ventral zone, called chambered part (Fig. 1A). The ventral zone contains the septa, the siphuncular zone and the fork (Fig. 1A); the posterior part of the cuttlebone is sharp and called rostrum or spine (Fig. 1B). In embryo, the dorsal shield is thin, and thanks to transparency, the complex outlines of the 
first septa are visible (Fig. 1C). The growth occurs anteriorly by a ventral addition of new septa, delimitating chambers sustained by pillars, all being slightly mineralized (Fig. 1D-F). The fork, wings and rostrum are absent in the embryo cuttlebones (Fig. 1C, D). At hatching, the shell is composed of 6 to 8 chambers (Fig. 1F).

The organization of the adult cuttlebone has been repeatedly described, so that only the main features are here shown. The microstructure and nanostructure are detailed and illustrated.

\section{Dorsal shield (= outer wall)}

\section{Adult shell}

Three main layers are present in the dorsal shield (Fig. 2A, B): a thick prismatic outer spherulitic layer, a layered median layer (type II nacre or lamello-fibrillar nacre) and a thin prismatic inner layer. The outer spherulitic prismatic layer is composed of several sublayers (Fig. 2A, B). The thickness of the sublayers is irregular, because of the spherulites seen on the outer surface and described as tubercles (Appellöf 1893). Growth layers are visible, made of elongated crystallites perpendicular to the sublayers (Fig. 2C). Etched and polished surfaces show the small diameter $(<1 \mu \mathrm{m})$ of the crystallites of the outer layer, so that they are more acicular than prismatic (Fig. 2D-E). Unetched oblique fractures in these acicular crystallites show the non-geometric shapes of granules (50-100 nm diameter) (Fig. 2F). The surface of the growth layers of the spherulitic prismatic layer reveals that the granules are not adjacent (Fig. 2G), and the large content of organic components is shown by AFM phase image contrast, as homogenous dark "flat" zones (Fig. 2H). The shades of colour in AFM phase image within a granule are indicative of a heterogeneous composition (Fig. 2I).

The median layer is thinner and shows overlapped sheets. The orientation of the acicular crystallites differs in every sheet (Fig. 3A). A cross-section shows that the sheets are stacked, parallel and thin (Fig. 3B, C) and some substructures perpendicular to the sheets are visible (Fig. 3C, stars). AFM height images show that a sheet is composed of rounded granules (Fig. 3D, E), and that the granules have a heterogeneous composition, as shown by shades of colour in phase contrast image (Fig. 3F).

The inner layer is prismatic and thin (Fig. 3G). Elongated crystallites are more or less divergent towards the ventral side of the shell (Fig. 3G). At larger magnifications, granules are 
irregular and do not seem aligned (Fig. 3H). They are composite (Fig. 3I), as shown by AFM phase image.

\section{Embryonic shell}

The embryonic dorsal shield begins to be organized and grows from posterior to anterior. At stage 24, the shell is still organic and the mineralization, even low, starts at stage 25 (Fig. 4A and see below, Raman analysis). At stage 27, the thickness of the dorsal shield is about 15 microns (Fig. 4B-C). The prismatic structure of the outer layer (OP) is not well defined (Fig. 4D), and the elongated crystallites are not distinct (Fig. 4D). No sublayer is visible. The median layer seems to be entirely organic (Fig. 4E) and no inner arrangement is evidenced. The inner layer, IP, is similar to the outer layer, OP (Fig. 4D), with a somewhat indistinct arrangement. Nevertheless, in some samples (the oldest one, i.e. stage 30), the elongated crystallites perpendicular to the boundary of the layer are visible (Fig. 4E, F), so that this layer is said to be prismatic. AFM phase images of the dorsal shield show rounded granules, and parallel elongated structures (Fig. 4G). Elongated structures are composed of several parallel units, the diameter of each one rangin 4 from 20 to $50 \mathrm{~nm}$ (Fig. 4H). In the three layers of the dorsal shield, similar rounded granules are present. They are surrounded by a cortex, as shown by amplitude, phase and height images (Fig. 4I-K, c). In phase image (Fig. 4J), the cortex is darker than the inner part of the granules, so that it contains more organic components. The presence of amorphous calcium carbonate cannot be excluded. The maximal observed diameter of the granules is about $100 \mathrm{~nm}$.

If the adult dorsal shield comprises three layers, at stages 27-30 the layers and structures are not very distinct. At stage 28, near the growing edge and on the lateral parts of the dorsal surface, a banding pattern of about 40-50 microns (Fig. 5A, B) and another one with thinner growth lines are present (Fig. 5C). The first tubercles resulting from the irregular thickness of the growth layer of the dorsal shield are visible (Fig. 5D). The posterior limit of every septum corresponding to the aperture is easily identified on the ventral face (Fig. 5E-G). The most posterior is a circular aperture corresponding to the open siphuncle (Fig. 5G).

After $24 \mathrm{~h}$ in vitro incubation of the embryo in a calcein-containing sea water, and observations using light and fluorescence microscopy, the progressive antero-posterior 
development of the shield covering progressively the growing septum by irregular waves (Fig. 5 $\mathrm{H}-\mathrm{K}$ ) is well visible as well as the development of the pillars in each chamber (Fig. $5 \mathrm{I}-\mathrm{K}$ ).

\section{Ventral zone: chambered zone, septa}

\section{Adult shell}

The ventral zone is porous. Longitudinal sections show parallel septa on which vertical pillars are inserted (Fig. 6A, Fig. S2A) so that chambers are reinforced. Pillars are covered by an organic membrane (Fig. 6B, C, m) with extensions parallel to the septa (Fig. 6B). In the adult chambers, minor growth zones are visible on the pillars (Fig. 6D, E). When the organic membranes on the surface of the pillars are removed, a granular structure is revealed, the granules being more or less arranged in columns (Fig. 6F, Fig. S2B). The average diameter of the granules is about $50 \mathrm{~nm}$ (Fig. 6G). Fractures parallel to the long axis or perpendicular to this axis show that pillars are not homogenous structures: the central part is hollow or soft (Fig. S2C, D).

Septa are composed of two layers (Fig. 6B, 6H: L). A closer examination shows a thin prismatic layer with crystallites perpendicular to the septa, and a lamello-fibrillar nacreous layer (Fig. 6C, H-I). Sections of the lamello-fibrillar nacre of the lamellae show the parallel arrangement of the superimposed sheets and lamellae seem to be well mineralized (Fig. 6J). The lamello-fibrillar nacre is composed of overlapped sheets and the orientation of acicular crystallites differs in two successive sublayers (Fig. 6K-L). The structure of the thin prismatic layer is similar to that of the inner layer of the dorsal shield.

\section{Embryonic shell}

As for the dorsal shield, the chambered part is not fully calcified so that the detailed structure is difficult to decipher. The outlines of septa are emphasized by the presence of more or less calcified zones, as shown by BSE images (Fig. 5E-G).

Septa comprise two parts: the pillars, perpendicular to the outer surface of the shell, and thin lamellae parallel to the outer surface of the shell. Pillars are not arranged in walls as in the adult shell, but they are isolated and their outline shows multiple folds (Fig. 7A, B). At the insertion of a pillar on a lamella, the basal part of the pillar is enlarged (Fig. 7C). Pillars are often branched (Fig. 7D, E, Fig. S2E). The surface of the lamellae between the pillars shows small granules (Fig. 7F, Fig. S2F). They are probably covered by a thin organic membrane, but no 
horizontal extensions are present. The pillars are composed of successive growth layers (Fig. 7D, E), and transverse sections show that the outer peripheral layer is more calcified (Fig. 7F).

The septum building starts with the secretion of a chitinous layer visible on the edge of the ventral zone (Fig. 5F, star). Lamellae on which pillars are inserted are composed of two layers, a prismatic layer and a lamello-fibrillar nacre, as observed in adult (Fig. 7G, H: L). The insertion of a septum on the dorsal shield in an embryonic shell does not show distinct structures (Fig. 7I). The two layers of the lamellae between the pillars are nanogranular (Fig. 7J), granules being embedded in an abundant matrix, probably organic as shown by AFM phase image (Fig. $7 \mathrm{~K}, \mathrm{~L})$. It must be noted that in adult shell, pillars merged in a zig zag pattern, while they are clearly separated and curly in embryonic shells (Fig. S2G).

Incubation of embryos in calcein-containing seawater reveals that calcification occurs in the pillars as soon as they start to grow from a dorsal septum to the future ventral one. The calcification is particularly located at the distal branching ends of each pillar until they connect with a new septum in formation (Fig. S2H, I).

\section{Rostrum}

In the adult shell, the rostrum is clearly visible as a sharp curved spine (Fig. 8A, B). Such sections also show the topographic relationships between the ventral fold, the fork, the dorsal shield and the first septa (Fig. 8A-C). The concentric structure is displayed in a transverse fracture (Fig. 8D) whereas the layered arrangement is shown in longitudinal sections (Fig. 8E, F). Despite the continuity between the dorsal shield and the rostrum, the growth layers of the rostrum are thinner and more regular than those of the dorsal shield (Fig. 8F), the rostrum being smaller and smoother than the dorsal surface of the shell. No tubercle is present on the rostrum. The thickness of the growth layers is variable, and these layers are composed of parallel elongated crystallites, similar to those of the dorsal shield (Fig. 8G). Depending on the orientation of the section and the thickness of the growth layers, the crystallites are more or less visible.

The rostrum is not developed at the studied embryonic stages (Fig. 1D-F, Fig. 8H-I). It starts to differentiate from one month, after hatching. 


\section{Fork - ventral process}

Fork is in contact and inserted on the inner prismatic layer of the dorsal shield (Fig. 8C, 9A). The fork is composed of parallel lamellae, the thickness of which is similar to those of the septa (Fig. 9B). Depending on the orientation of the fracture, the aspect of the lamellae differs (Fig. 9B, C), but a closer examination shows that the compact lamellae comprise two sublayers: one sublayer is "prismatic" (Fig. 9D, 1), the second one being more "lamellar" (Fig. 9D: 2). The boundary between these two sublayers is not distinct, and their thickness is irregular. Thus, in some fractures, one of these sublayers is not pulled out (Fig. 9C).

The ventral fold, also called ventral process (Fig. 8A-B), shows a radial structure, composed of a series of thin organic and mineralized layers (Fig. 9E). The prismatic structure of the mineralized layers is similar to that of the outer layer of the dorsal shield (Fig. 9F).

Fork and ventral process are not differentiated in the embryonic shells (Fig. 1C, 4A, E).

\section{Composition of adult and embryonic samples}

The spectra of the calcite and aragonite groups are characterized by three major bands attributed to the carbonate ion $\mathrm{CO}_{3}{ }^{2-}: \mathrm{v} 3$ at $1429 \mathrm{~cm}^{-1}$, the $v 2$ doublet $877-848 \mathrm{~cm}^{-1}$, and $v 4$ at $713 \mathrm{~cm}^{-1}$ for the calcite group; $v 3$ at $1471 \mathrm{~cm}^{-1}$ and two doublets: $v 2$ at $858-844 \mathrm{~cm}^{-1}$ and $v 4$ at $713-700 \mathrm{~cm}^{-}$ ${ }^{1}$ for the aragonite group (Adler and Kerr 1963). The weak $v 1$ band is at $1012 \mathrm{~cm}^{-1}$ for calcite and at $1083 \mathrm{~cm}^{-1}$ for aragonite (Jones and Jackson 1993). According to Ylmen and Jäglid (2013), the v3 asymmetric stretching of $\mathrm{CO}_{3}{ }^{2-}$ has a larger wavenumber range from 1425 and $1590 \mathrm{~cm}^{-1}$.

The FTIR spectrum of the geological aragonite used as standard shows these main features (Fig. 10).

The dorsal shield and ventral chambered zone of adult shells also displayed the main bands assigned to aragonite: $v 1$ at $1083 \mathrm{~cm}^{-1}, v 2$ doublet at $860-878 \mathrm{~cm}^{-1}$ and a doublet $v 4$ at $700-713 \mathrm{~cm}^{-1}$. Strong bands are visible respectively at 1512 and $1514 \mathrm{~cm}^{-1}$. Unfortunately, in this region (1400-1600 $\mathrm{cm}^{-1}$ ), protein and chitin have characteristic amide I and II bands, and aragonite has an intense $v 3$ vibration band at $1483 \mathrm{~cm}^{-1}$. The spectral pattern between 1644 and $1510 \mathrm{~cm}^{-1}$ shows 2 intense bands probably indicative of a mixture of organic and mineral $\left(\mathrm{CO}_{3}{ }^{2-}\right)$ components. The bands at 1657 and $1644 \mathrm{~cm}^{-1}$ could be attributed to amide I vibration, whereas, the bands at 1512 and $1514 \mathrm{~cm}^{-1}$ are probably a mixture of amide $\mathrm{II}$ and $\nu 3 \mathrm{CO}_{3}{ }^{2-}$ vibrations. 

between 1050 and $1150 \mathrm{~cm}^{-1}$ are known to be characteristic for sugars. Although these bands are not clearly observed on both spectra, previous results (Le Pabic et al. 2017) and Fig S3 confirm the presence of sugars (large CO vibration band around 1030-1070 $\mathrm{cm}^{-1}$ ). The main part of the dorsal shield is the prismatic outer layer, low in organic components. Organic matrices in the form of abundant lamellae exist in the ventral part, so that chitin is more abundant.

The size of embryonic samples does not allow to separate the dorsal shield and the septa, so that the whole samples were powdered for FTIR analyses. The "mineral bands" ( $v 1$ to $v 4$, Fig. 10) are weak. As observed in the adult spectra, 1456 and $1639 \mathrm{~cm}^{-1}$ bands can be assigned to amide vibrations from both proteins and chitin. The characteristic sugar band at $1030-1070 \mathrm{~cm}^{-1}$ is probably hidden by the spectrum background (as also observed for the adult spectra).

To sum up, in all non decalcified samples, bands assigned to organic components are present, but they represent a mixture of proteins, chitin and lipids, so that a precise assignment is not possible. Spectra of the embryonic (green) and adult (orange and blue) shells are indicative of a mixed mineral - organic composition, with very low mineral content in the case of the juvenile shell.

One of the advantages of Raman spectroscopy is the small size of the beam $(\sim 5 \mu \mathrm{m}$ with the green laser), allowing precise in situ punctual analyses. Regarding the first appearance of mineralisation, this was detected by micro-Raman spectroscopy at stage 25 . The spectrum obtained (Fig. 11) is characteristic of a crystalline polymorph of calcium carbonate, more precisely aragonite, with main peaks at 152, 206, 701-705 and $1085 \mathrm{~cm}^{-1}$ (Urmos et al. 1991; Wehrmeister et al. 2011). The strongest band at $1085 \mathrm{~cm}^{-1}$ is an internal mode that derives from the symmetric stretching mode $(v 1)$ of carbonate ions. The peaks visible at 152 and $206 \mathrm{~cm}^{-1}$ correspond to translational and rotational lattice modes of aragonite carbonate ions, respectively. The doublet $701-705 \mathrm{~cm}^{-1}$, specific for aragonite, corresponds to the in-plane bending ( $\mathrm{v} 4$ ) mode of aragonite carbonate ions.

Moreover, aragonite is already present whatever the parts of the cuttlebone analysed (pillar, septa, even at the level of the chamber in formation), suggesting that the calcification is concomitant to the growth process. Note that ACC (amorphous calcium carbonate, precursor of any crystalline polymorph) was never evidenced. The mineralization seems to be happening directly as aragonite. 


\section{Discussion}

\section{Anatomy and structure}

The anatomy and organisation of the adult cuttlebone of Sepia are known since the work of Appellöf (1893). Since, the relationships between the different elements (rostrum, fork...) have been more precisely defined (Dauphin 1979, 1981; Cadež et al. 2017).

In Sepia officinalis, the septa as well as the dorsal shield are made of three layers, a thick "prismatic" outer layer, a lamello-fibrillar "nacre" and a thin "prismatic" inner layer. All layers are built with elongated acicular crystallites, parallel to the surface of the shell in the lamellofibrillar "nacre", perpendicular in the prismatic layers. These last ones, from a morphological point of view and despite they are called "prismatic", clearly differ from other aragonitic prismatic layers known in other mollusc shells (e.g., Unionids: Dauphin et al. 2017, Schoeppler et al. 2018). The crystallites are not organized in large prisms, the reason why these layers are called "fibres" in some taxa. These prismatic layers are more similar to the aragonitic "fibres" from coral skeletons (Cuif and Dauphin 2005; Cuif 2016). The absence of tablets in the lamellofibrillar "nacre" is also confirmed.

The lamellar aspect observed for all the layers and the presence of parallel elongated crystallites were described by Grégoire (1961), then Mutvei (1964) The changes in the crystallite orientation at every lamella as well as the absence of tablets were also observed by these authors. Since, SEM observations have confirmed that such a structure is present in Spirula (Dauphin 1976; Bandel and von Boletzky 1979), and belemnites (Doguzhaeva et al. 2003).

All the modern cephalopod shells are aragonitic, with different structures. The prismatic layers are diverse in structure and thickness. For example, in modern shells, the lamellar layer is thick and calcified (as here in Sepia but also in Nautilus) or very thin and organic (outer wall in Spirula). Note that in Spirula, the nacreous layer is the thickest part of the septa and is strongly mineralized (Mutvei 1964).

The outer surface of the dorsal shield of Sepia is not smooth, and the presence of tubercles is due to irregular spherulites. In the outer layer of the shell of Nautilus, irregular spherulites also exist, so that this layer is said to be spherulitic prismatic (Mutvei 1964). Similar 
structures also exist in fossil genera: Belosepia, Beloptera and Belopterina (Dauphin, 1984, 1985, 1986).

Despite these different microstructures, high-resolution SEM and especially AFM reveal, at the nanolevel, that all the aragonitic layers are made of rounded heterogeneous granules (diameter $<100 \mathrm{~nm}$ ). The abundance of the organic matrices, around (and probably within) the granules, is shown by AFM phase images and BSE-SEM images.

Another feature is the complex structure of the pillars. Not only they show an organic envelope, growth zones and granules, but transversal sections reveal that their inner structure is heterogeneous: the central zone is sometimes empty or is more organic that the outer layer. (Fig. S2C, D). It must be added that the shape of the pillars is not constant: curly and isolated in the embryo, they are connected in zig zag wall in the adult shell.

All the morphological elements found in the adult shell exist in the embryonic shell but only the dorsal shield and the septa with pillars are visible at the hatching phase. The anatomy of the first stages of the cuttlebone has been described but most studies are focused on the number of septa and shape of the pillars. The cuttlebone of Sepia officinalis appears at stage 24 as a fully organic structure in a closed shell sac, the first calcified layers appear between stage 24 and 25 and the first pillars are built as soon as the formation of the second septa with the formation of the first chamber (Bandel and Boletzky 1979, Le Pabic et al. 2016).

The three layers of the dorsal shield are visible, despite the microstructural elements (prisms or lamello-fibrillar nacre) are not so well differentiated. Embryonic shell shows that growth lines are visible in the pillars of the ventral part as soon as stage 29 (Le Pabic et al. 2016). They are also clearly visible in SEM images, as well as the prismatic structure. Rostrum is a weak bump at stage 30 , with a structure similar to that of the dorsal shield. Fork and ventral process are not differentiated in the newly hatched shell, and "wings" are absent or not developed. They are lateral extensions of the dorsal shield (Barskov 1973; Dauphin 1981), and their surface is granular (Fig. S2F).

In most fossil sepiids, the ventral region and the fragile structure of the pillars are not preserved. Lamellae and pillars are visible in Miocene Sepiids from Australia, but their inner structure is not displayed (Košt'ák et al. 2017). A change in wall/pillar configuration between the different regions of the cuttlebone (lateral areas $v s$ median and latero-median areas) has been reported both in Sepia (extant species) and Belosaepia (fossil species) (Sherrard 2000; Yancey et 
al. 2010). A recent study performed using CT-scan study did not evidenced such a difference in adult Sepia cuttlebone (Le Pabic et al. 2019). Actually Košt'ák et al. (2016) have not evidenced any imprints of pillar in the exceptionally preserved embryonic part of the holotype of $S$. vindobonensis, or in specimen NHMW 2004z0076/0039 of S. aff. sanctacrucensis. In this case, the development of pillars in the embryonic shell of extant cephalopods could represent an evolutionary novelty. Nevertheless, our results have shown that calcification of the embryonic shell is very light so that it cannot be excluded that these very small embryonic pillars have disappeared during fossilisation.

\section{Composition}

FTIR analyses show clearly that both the embryonic and the adult Sepia cuttlebones are composed of biogenic aragonite (result confirmed by Raman spectroscopy), which means they are made of a mixture of a crystalline polymorph of $\mathrm{CaCO}_{3}$ and an inner organic matrix. The spectra obtained from the powdered dorsal shield and the ventral chambered part exhibit bands corresponding mainly to aragonite, proteins, chitin and other carbohydrates. FTIR spectra of the soluble and insoluble matrices resulting from the decalcification of the ventral zone and dorsal shield have been provided by Le Pabic et al. (2017). Whereas bands associated with proteins (vibrational amide bands) appear in the two spectra, bands associated with carbohydrates are more important in the insoluble matrix (but stronger in the chambered part than in the dorsal shield probably linked to the presence of an abundant matrix inside the chambers).

\section{Mineralization}

Raman analyses allowed deciphering the calcification process during the development of the cuttlebone from the embryo to the adult. Until stage 24 embryo, the shell in formation appears fully organic. From stage 25, calcification is detected by the presence of bands characteristic of $\mathrm{CaCO}_{3}$, wherever the area analysed, which means that this process starts in all the cuttlebone at the same time. From this stage, the cuttlebone can then be considered as a biomineral, mixture of mineral and organic components.

Raman and FTIR spectroscopy techniques confirm that the $\mathrm{CaCO}_{3}$ polymorph of the adult is aragonite as already reported. As for this adult shell, although the polymorph is crystalline for all the layers, the nanostructure reveals that they are composed of irregular 


\section{Conclusion}

The examination of adult shells of Sepia officinalis shows that despite a particular morphology, the main layers of the cephalopod shell are present. The dorsal shield comprises three layers, the thickness and mineralization degree of which differs. The ventral part (pillars and lamellae) represents the septa and the siphuncular zone.

In both septa and dorsal shield, the middle layer is lamellar, with acicular crystallites, as the classical nacreous layer but the tablets are absent. Pillars of the ventral zone are not 
homogeneous: the inner part is more organic than the outer part, as displayed by longitudinal and transverse sections. Rostrum, absent in embryo, is an extension of the dorsal shield.

Despite differences in the structure of the layers, and despite the crystalline structure of the constitutive mineral, all microstructural units are composed of more or less rounded granules (diameter between 50 and $100 \mathrm{~nm}$ ). The organic matrix contains mainly chitin and proteins, but also, in a lesser extent, other carbohydrates and lipids, as in all the calcified biominerals.

In the embryonic shell, an early mineralization, directly as aragonite, is detected at stage 25 . At stages 28 and 29, before hatching, the shell has about 6 chambers septa, and is still weakly mineralized. The micro- and nanostructures of the pillars and lamellae of the ventral zone are similar to those of adult shells, despite the pillars are branching, and not yet linked to form undulating walls. Growth lines are visible, as well as granules. Fork, ventral process and rostrum are not yet differentiated. Chitin is probably the main component of the embryonic shell, and FTIR profile is more similar to the ventral zone of an adult shell (less mineralized) than to the dorsal shield.

\section{Acknowledgements}

This work was financially supported by the ATM "Interactions Minéral - Vivant" funding of the Muséum national d'Histoire naturelle (SEPIOM project). The authors thank all the members of the Max Planck Institute for Interfaces and Colloids (Golm, Germany) for their help. We thank C. Jozet-Alves and the CREC (University of Caen) for providing eggs of Sepia officinalis. LBP thanks G. Patriache and L. Largeau (CNRS-LPN) for the first tests on mineral composition of embryonic shell several years ago.

\section{Compliance with ethical standards}

Animal protocols were carried out in accordance with European legislation (directive 2010-63UE and French decree 2013-118).

\section{Conflict of interest}

Authors declare that they have no conflict of interest. 


\section{Research involving human and animal participants}

We neither used endangered species nor were the investigated animals collected in protected areas.

\section{References}

Adler HH, Kerr PF (1963) Infrared absorption frequency trends for anhydrous normal carbonates. Am Mineral 48:839-853

Allcock AL, Lindgren A, Strugnell J (2015) The contribution of molecular data to our understanding of cephalopod evolution and systematics: a review. J Nat History 49:13731421

Appellöf A (1893) Die Schalen von Sepia, Spirula und Nautilus. Studien über den Bau und das Wachstum. K Svenska Akad Handl Stockholm 25(7):1-106

Bandel K (1990) Cephalopod shell structure and general mechanisms of shell formation. In: Skeletal Biomineralization: Patterns Processes and Evolutionary Trends, Vol 1, Carter JG (ed). Van Nostrand Reinolds, New York, pp 97-115

Bandel K, Boletzky S von (1979) A comparative study of the structure, development and morphological relationships of chambered cephalopod shells. Veliger 21(3):313-354

Barskov IS (1973) Microstructure of the skeletal layers of Sepia and Spirula compared with the shell layers of other molluscs. Paleont J 3:285-294

Bettencourt V, Guerra A (2001) Age studies on daily growth increments in statoliths and growth lamellae in cuttlebone of cultured Sepia officinalis. Mar Biol 139:327-334

Boggild OB (1930) The shell structure of the molluscs. D Kgl Danske Vidensk Selsk Skr, naturvidensk og mathem 9(2):231-326

Boletzky S von, Andouche A, Bonnaud-Ponticelli L (2016) A developmental table of embryogenesis in Sepia officinalis. Vie Milieu 66(1):25-34

Butler-Struben HM, Brophy SM, Johnson MA, Crook RJ (2018) In vivo recording of neural and behavioral correlates of anesthesia induction, reversal, and euthanasia in cephalopod molluscs. Front Physiol 9:109. doi: 10.3389/fphys.2018.00109 
Cadež V, Škapin SD, Leonardi A, Križaj I, Kazazic S, Salopek-Sondi B, Sondi I (2017)

Formation and morphogenesis of a cuttlebone's aragonite biomineral structures for the common cuttlefish (Sepia officinalis) on the nanoscale: Revisited. J Colloid Interface Sci 508:95-104

Checa AG, Cartwright JHE, Sanchez-Almazo I, Andrade JP, Ruiz-Raya F (2015) The cuttlefish Sepia officinalis (Sepiidae, Cephalopoda) constructs cuttlebone from a liquid-crystal precursor. Sci Rep 5:11513. doi: 10.1038/srep11513

Cuif JP (2016) Calcification in the Cnidaria through time: an overview of their skeletal patterns from individual to evolutionary viewpoints. In: The Cnidaria, Past, Present and Future, Goffredo S, Dubinsky Z (eds) Springer, pp 163-179

Cuif JP, Dauphin Y (2005) The two-step mode of growth in the scleractinian coral skeletons from the micrometre to the overall scale. J Struct Biol 150:319-331

Cuif J, Dauphin Y, Denis A, Gaspard D, Keller JP (1983) Etude des caractéristiques de la phase minérale dans les structures prismatiques du test de quelques Mollusques. Bull Mus Natl Hist Nat, Paris, 4è sér, 5 A, 3:679-717

Cuif JP, Bendounan A, Dauphin Y, Nouet J, Sirotti F (2013) Synchrotron-based photoelectron spectroscopy provides evidence for a molecular bond between calcium and mineralizing organic phases in invertebrate calcareous skeletons. Anal Bioanal Chem 405(27): 87398748

Dauphin Y (1976) Microstructure des coquilles de Céphalopodes: I. Spirula spirula L.

(Dibranchiata, Decapoda). Bull Mus natn hist nat, Paris, 3è sér., 382, Sciences de la terre 54: 197-238.

Dauphin Y (1979) Organisation ultrastructurale de l'os de seiche (Cephalopoda-Dibranchiata) C R Acad Sc Paris D 288: 619-622

Dauphin Y (1981) Microstructures des coquilles de Céphalopodes. II- La seiche (Dibranchiata, Decapoda). Palaeontogr A176:35-51

Dauphin Y (1984) Microstructures des coquilles de Céphalopodes. IV- Le "rostre" de Belosepia (Dibranchiata). Palaeontogr Z 58(1/2):99-117

Dauphin Y (1985) Microstructural studies on cephalopod shells. V- the apical part of Beloptera (Dibranchiata, Tertiary). N Jb Geol Palaeont Abh 170(3):323-341 
Dauphin Y (1986) Microstructure des coquilles de Céphalopodes: la partie apicale de Belopterina (Coleoidea). Bull Mus natn Hist nat, Paris, 4e sér., 8, section C 1: 53-75

Dauphin Y, Keller JP (1982) Mise en évidence d'un type microstructural coquillier spécifique des Céphalopodes dibranchiaux. C R Acad Sc Paris sér. II 294:409-412

Dauphin Y, Luquet G, Salomé M, Bellot-Gurley L, Cuif JP (2017) Structure and composition of Unio pictorum shell: arguments for the diversity of the nacroprismatic arrangement in molluscs. J Microscopy 270(2):156-169

Dauphin Y, Williams CT, Barskov IS (2007) Aragonitic rostra of the Turonian belemnitid Goniocamax: Arguments from diagenesis. Acta Palaeont Pol 52:85-97

Degens ET, Spencer DW, Parker RH (1967) Paleobiochemistry of molluscan shell proteins. Comp Biochem Physiol 20(2):553-579

Doguzhaeva L, Dunca E (2015) Siphonal zone structure in the cuttlebone of Sepia officinalis. Swiss J Palaeontol 134:167-176

Doguzhaeva L, Mutvei H, Weitschat W (2003) The pro-ostracum and primordial rostrum at early ontogeny of lower Jurassic belemnites from North-Western Germany. In: Coleoid cephalopods through time, Warnke K, Keupp H, Boletzky von S (eds) Berliner Paläobiol Abh 03, pp 79-89

Dorey N, Melzner F, Martin S, Oberhänsli F, Teyssié JL, Bustamante P, Gattuso JP, LacoueLabarthe T (2013) Ocean acidification and temperature rise: effects on calcification during early development of the cuttlefish Sepia officinalis. Mar Biol 160:2007-2022

Drozdova TV, Karyakin AV, Krasnova VA (1971) Chemical composition and infra-red absorption spectra of the organic matrix of the shell in the squid Sepia pharaonis. J Evol Biochem Physiol 7(4):350-356

Ehrenberg C.G. (1828-1831). Animalia evertebrata exclusis Insectis. Series prima. In: F.G. Hemprich \& C.G. Ehrenberg, Symbolae physicae, seu icones et descriptiones Mammalium, Avium, Insectorum et animalia evertebra, quae ex itinere per Africam borealem et Asiam occidentalem studio nova aut illustrata redierunt. 126 pp. (1831), 10 pls (1828)

Erben (1972) Über die Bildung und das Wachstum von Perlmutt. Biomineralisation 4:15-46. 
Florek M, Fornal E, Gomez-Romero P, Zieba E, Paszkowicz W, Lekki J, Nowak J, Kuczumow A (2009) Complementary microstructural and chemical analyses of Sepia officinalis endoskeleton. Mater Sci Engin C29:1220-1226

Grégoire C (1961) Sur la structure de la nacre septale des Spirulidae, étudiée au microscope électronique. Arch Int Physiol Biochim 69(3):374-377

Grégoire C (1967) Sur la structure des matrices organiques des coquilles de mollusques. Biol Rev 42:653-688

Gutowska MA, Pörtner HO, Melzner F (2008) Growth and calcification in the cephalopod Sepia officinalis under elevated seawater $\mathrm{pCO}_{2}$. Mar Ecol prog Ser 373:303-309

Haas W (2003) Trends in the evolution of the Decabrachia. Berliner Paläobiol Abh 3:11-12

Hunt S, Nixon M (1981) A comparative study of protein composition in the chitin-protein complexes of the beak, pen, sucker disc, radula and oesophageal cuticle of cephalopods. Comp Biochem Physiol 68B:535-546

Jones GC, Jackson B (1993) Infrared transmission spectra of carbonate minerals. Springer Science, $239 \mathrm{pp}$

Karthika R, Manigandan V, Saravanan R, Rajesh RP, Chandrikada B (2016) Structural characterization and in vitro biomedical activities of sulfated chitosan from Sepia pharaonis. Int J Biol Macromol 84:319-328

Kim BS, Kim JS, Sung HM, You HK, Lee J (2012) Cellular attachment and osteoblast differentiation of mesenchymal stem cells on natural cuttlefish bone. J Biomed Mater Res 100A:1673-1679

Košt'ák M, Schlögl J, Hudáčková N, Kroh A, Halásová E, Gašparič R, Matúš Hyžný, Wanzenböck G (2016) Sepia from the Miocene of the Central Paratethys: new taxa and notes on late Cenozoic cuttlefish diversity. J System Paleontol 14(12):1033-1057

Košt'ák M, Ruman A, Schlögl J, Hudácková N, Fuchs D, Mazuch M (2017) Miocene sepiids (Cephalopoda, Coleoidea) from Australia. Foss Rec 20:159-172

Kröger B, Vinther J, Fuchs F (2011) Cephalopod origin and evolution: A congruent picture emerging from fossils, development and molecules. Bioessays 33:602-613

Le Pabic C, Rousseau M, Bonnaud-Ponticelli L, Boletzky S von (2016) Overview of the shell development of the common cuttlefish Sepia officinalis during early-life stages. Vie et Milieu 66(1):35-42 
Le Pabic C, Marie A, Marie B, Percot A, Bonnaud-Ponticelli L, Lopez PJ, Luquet G (2017) First proteomic analyses of the dorsal and ventral parts of the Sepia officinalis cuttlebone. J Proteomics 150:63-73

Le Pabic C, Derr J, Luquet G, Lopez P-J, Bonnaud-Ponticelli L (2019) Three-dimensional structural evolution of the cuttlefish Sepia officinalis shell from embryo to adult stages. J R Soc Interface 16(158): 20190175. doi: 10.1098/rsif.2019.0175

Lemaire J (1970) Table de développement embryonnaire de Sepia officinalis L. (Mollusque, Céphalopode). Bull Soc zool Fr 95:773-782

Linnaeus C. (1758). Systema Naturae per regna tria naturae, secundum classes, ordines, genera, species, cum characteribus, differentiis, synonymis, locis. Editio decima, reformata [10th revised edition], vol. 1: 824 pp.

Lowenstam HA, Weiner S (1989) On Biomineralization, Oxford University Press, 323 pp

Marie B, Marin F, Marie A, Bédouet L, Dubost L, Alcaraz G, Milet C, Luquet G (2009)

Evolution of nacre: biochemistry and proteomics of the shell organic matrix of the cephalopod Nautilus macromphalus, Eur J Chem Biol 10:1495-1506

Mutvei H (1964) On the shells of Nautilus and Spirula with notes on the shell secretion in non cephalopod mollusks. Arkiv Zool 16:221-278

Mutvei H (1970) Ultrastructure of the mineral and organic components of molluscan nacreous layers. Biomineralisation 2:48-61

Mutvei H (2016) Siphuncular structure in the extant Spirula and other Coleoids (Cephalopoda). GFF 139(2):129-139

Naef A (1922) Die fossilen Tintenfische. Carl Fisher ed., Jena, 322 pp

Naef A (1928a) Die Cephalopoden Embryologie. In Fauna und Flora des Golfes von Neapel und der angrenzenden Meeres- Abschnitte. Berlin, Friedländer, 357 pp

Naef A (1928b) Die Cephalopoden. In: Fauna und Flora des Golfes von Neapel. Verlag, von R. Friedländer \& Sohn, Berlin, 863 pp

Ogasawara W, Shenton W, Davis SA, Mann S (2000) Template mineralization of ordered macroporous chitin-silica composites using a cuttlebone-derived organic matrix. Chem Mater 12:2835-2837

Schoeppler V, Granasy L, Reich E, Poulsen N, de Kloe R, Cook P, Rack A, Pusztai T, Zlotnikov I (2018) Biomineralization as a paradigm of directional solidification: A physical model 
for Molluscan shell ultrastructural morphogenesis. Adv Mater 30(45): e1803855. doi:

10.1002/adma.201803855

Sen H (2013) The cuttlebone development of common cuttlefish [Sepia officinalis (Linneaus, 1758)]. Ege J Fish Aqua Sci 30:105-108

Sherrard KM (2000) Cuttlebone morphology limits habitat depth in eleven species of Sepia (Cephalopoda: Sepiidae). Biol Bull 198:404-414

Sigwart JD, Lyons G, Fink A, Gutowska MA, Murray D, Melzner F, Houghton JDR, Hu MY (2015) Elevated $\mathrm{pCO}_{2}$ drives lower growth and yet increased calcification in the early life history of the cuttlefish Sepia officinalis (Mollusca: Cephalopoda). ICES J Mar Sci 73:970-980

Sykes AV, Domingues P, Andrade JP (2014) Sepia officinalis. In: Iglesias J, Fuentes L, Villanueva R (eds), Cephalopod Culture. Springer, Dordrecht, pp 175-204

Urmos, J., Sharma, S.K., Mackenzie, F.T. (1991) Characterization of some biogenic carbonates with Raman spectroscopy. Am Mineral 76:641-646

Wehrmeister U, Jacob DE, Soldati AL, Loges N, Häger T, Hofmeister W (2011) Amorphous, nanocrystalline and crystalline calcium carbonates in biological materials. J Raman Spectrosc 42:926-935

Winlow W, Polese G, Moghadam H-F, Ahmed IA, Di Cosmo A (2018) Sense and Insensibility An appraisal of the effects of clinical anesthetics on Gastropod and Cephalopod molluscs as a Step to Improve welfare of Cephalopods. Front Physiol 9:1147. doi:

10.3389/fphys.2018.01147

Yancey TE, Garvie CL, Wicksten M (2010). The middle Eocene Belosaepia ungula (Cephalopoda: Coleoida) from Texas: structure, ontogeny and function. J Paleontol 84(2):267-287

Ylmen R, Jäglid U (2013) Carbonation of Portland cement studied by diffuse reflection Fourier transform infrared spectroscopy. Int J Concr Struct Mater 7(1):119-125

\section{Legends of figures}

Fig. 1 Comparison of the morphologies of adult and embryonic shells of Sepia officinalis. 
A-B Views of an adult shell showing the main morphological parts, A Ventral view, B Dorsal view. C Dorsal view of a stage 29 embryonic shell. D-F In situ localisation of embryonic shells, D Lateral view on a stage 27 embryo (X-ray image, note the mineralized statocysts anteriorly st), E Dorsal view on a stage 27 embryo, F Dorsal view on a stage 29 embryo. All the shells are shown in the same position, at the top: anterior part, on the bottom: posterior part. (A-C photographs, E-F optical images, D X-ray image)

Fig. 2 Micro- and nanostructure of the outer spherulitic prismatic layer of the dorsal shield of the adult shell of Sepia officinalis.

A Oblique fracture showing the outer surface of the dorsal shield with strong tubercles (SESEM). B Transversal section showing the three layers (BSE-SEM). C Detail of the outer spherulitic prismatic layer showing the irregular thickness of the growth layers, and their inner structure composed of acicular crystallites (BSE-SEM). D Detail of the elongated crystallites in a growth layer of the outer spherulitic prismatic layer (BSE-SEM). E AFM height image of acicular crystallites of the outer spherulitic prismatic layer. F AFM phase image showing that acicular crystallites of a polished and etched section comprises rounded granules. G AFM phase image of the surface of a growth layer, showing the rounded granules scattered in a dark matrix, probably organic. H AFM height image showing a granule in the same sample. I AFM phase image of the same zone showing that despite the bleaching, the organic matrix (dark zone) is still abundant so that the outline of the granules is blurred (dotted line). B-F Sections polished and etched by formic acid $10 \%$ for $2 \mathrm{sec}$. G-I Sections treated by commercial $\mathrm{NaOCl}(2.6 \% \mathrm{Cl})$ for $100 \mathrm{~min}$.

Fig. 3 Micro- and nanostructure of the lamello-fibrillar nacre (A-F) and the inner prismatic layer (G-I) of the dorsal shield of the adult shell.

A Lamello-fibrillar nacre, composed of elongated crystallites parallel to the surface of the layer, with diverse orientations $\left(\mathrm{H}_{2} \mathrm{O}_{2} 33 \%\right.$ for $2 \mathrm{~min}$., $\left.20^{\circ} \mathrm{C}\right)$; SE-SEM. B Unetched transverse fracture showing the parallel sheets; SE-SEM. C Some sheets have substructures (yellow stars); unetched fracture; SE-SEM. D, E Two different magnifications of the same zone showing nanogranules 
within the sheets ; AFM height image (polished and etched section, acetic acid $2 \%$ for $5 \mathrm{sec}$.). F AFM Phase image of the nanogranules showing the abundant organic matrix (D-F same sample). G Unetched fracture in the inner prismatic layer showing elongated crystallites; SE-SEM. H AFM phase image showing irregular granules (polished and etched section, acetic acid 2\% for 5 sec.). I Magnification of $\mathrm{H}$ showing the heterogeneity of the granules.

Fig. 4 Micro- and nanostructures of the dorsal shield of embryonic shells. A stage 24, B-K stage 27.

A Organic stage 24 embryonic shell. Septa, wings and rostrum are not differentiated. B Longitudinal polished and etched section of a stage 27 embryonic shell showing the dorsal shield and some septa (formic acid $0.1 \%$ for $10 \mathrm{sec}$.). C Detail of Fig. 4B showing the insertion of a septum (S) on the dorsal shield (DS); BSE-SEM. D Vertical section showing the poorly calcified shell layers. OP: outer spherulitic prismatic layer, IP: inner prismatic layer (section polished and etched by acetic acid $2 \%$ for $5 \mathrm{sec}$.); BSE-SEM. E Vertical section showing the irregular thickness of the layers, and the mainly organic middle layer (section polished and etched by formic acid $0.1 \%$ for $10 \mathrm{sec}$.); BSE-SEM. F Parallel crystallites in the inner prismatic layer; unetched fracture, BSE-SEM. G AFM phase image showing that rounded granules are more or less arranged in columns in some parts of the dorsal shield (section polished and etched by acetic acid $2 \%$ for $5 \mathrm{sec}$.). $\mathbf{H}$ The size and shapes of the heterogeneous granules are irregular; AFM phase image, same sample. I AFM amplitude image showing the rounded granules dispersed in the abundant organic matrix (C: cortex); same sample. J AFM phase image of the same area. $\mathbf{K}$ AFM height image showing the cortex surrounding the granules in a section of the dorsal shield; same sample.

Fig. 5 Morphology of embryonic shell. A-G stage 28, H-J stage 26, K stage 30

A Dorsal view showing the absence of rostrum. B Detail of the lateral part of the shell showing growth ridges; dorsal view. C Another aspect of the outer surface of the dorsal shield showing two growth rhythms: between the arrows, thin growth layers are visible. D First tubercles on the 
dorsal surface. E Ventral view showing the first septa. F Detail of the lateral part showing the first stages of formation of the pillars. G Detail of the posterior zone of the ventral surface. (A-G SE-SEM pictures). H-K After in vitro incubation of the embryo in a calcein-containing sea water, the progressive antero-posterior development of the shield covering progressively the growing septum by irregular waves is well visible (H-I light microscopy, J-K fluorescence microscopy). Note that the development of the pillars in each chamber can be also observed by transparency.

Fig. 6 Micro- and nanostructure of the ventral part of the adult shell.

A Pillar (pi) part of the septa, connected in a zig zag wall inserted on a lamella (L); tangential unetched fracture. B Oblique fracture showing the thin lamellae (L) separated by pillars (pi). Pillars are connected by organic membranes $(\mathrm{m})$. C Fracture showing the prismatic layer $(\mathrm{P})$ and the lamello-fibrillar nacre $(\mathrm{N})$ of a lamella (L); pillars (pi) are covered by organic membranes (m). D Unetched fracture showing growth layers on the surface of a pillar. Insert: the pillar. $\mathbf{E}$ AFM height image showing growth layers of a pillar (acetic acid 2\% for $5 \mathrm{sec}$.). F When the tangential membranes are removed, granules of the pillars are revealed. G AFM height image of the rounded granules of a pillar (section polished and etched by acetic acid $0.1 \%$ for $5 \mathrm{sec}$.). $\mathbf{H}$ Transverse unetched fracture of a pillar (pi) with an enlarged base, the lamello-fibrillar nacreous layer $(\mathrm{N})$ and the prismatic layer $(\mathrm{P})$ of the lamellae (L). I Detail showing the parallel crystallites in the lamello-fibrillar nacre. J Unetched tangential section of a lamella, showing elongated crystallites in the lamello-fibrillar nacre, the orientation of which differs in the successive sublayers. K Unetched oblique section of the lamello-fibrillar nacre, showing the lamellar arrangement; AFM phase image. $\mathbf{L}$ Unetched surface of the lamello-fibrillar nacre, showing that the variable shapes and orientations of the crystallites. A, C, L: SE-SEM images. B, D-K: BSESEM images.

Fig. 7 Micro- and nanostructure of the ventral zone of the embryonic stage 28 shell.

A Curly aspect of the pillars inserted on a lamella (L) in an unetched tangential fracture; BSESEM. B Detail of a pillar. C Broken pillar showing the enlargement of the basal part, here separated from the lamella; BSE-SEM. D, E Surface of a pillar showing the fibrous structure of 
the growth layers and the branching towards the insertion on the lamella (L); BSE-SEM. F Unetched transverse section of a pillar showing an outer layer and an inner core; BSE-SEM. G Section showing the lamello-fibrillar nacre $(\mathrm{N})$ and prismatic $(\mathrm{P})$ layers of a lamella $(\mathrm{L})$ of one of the first septum; BSE-SEM. H Similar section, showing the enlargement of the pillar at the insertion on the lamella (L); SE-SEM. I Insertion of a septum on the dorsal shield (section polished and etched by acetic acid $2 \%$ for $5 \mathrm{sec}$ ); BSE-SEM. J AFM height image of a polished and etched lamella, showing a granular structure (acetic acid $2 \%$ for $5 \mathrm{sec}$.). K AFM phase image showing the abundance of the organic matrix (dark brown); same sample. L AFM amplitude image of a granule showing the complex composition of a granule of the lamellae; same sample.

Fig. 8 Rostrum of the adult shell (SE-SEM).

A Polished and etched longitudinal section showing a well-developed rostrum (formic acid 10\% for $30 \mathrm{sec}$.). B Section of the posterior part of an adult shell, redrawn from Appellöf (1893). C Longitudinal fracture showing the continuity of the outer layer of the dorsal shield and the rostrum. D Transverse fracture showing the concentric arrangement of the rostrum. E Polished and etched longitudinal section showing the growth layers, and the more or less mineralized zones (formic acid $10 \%$ for $30 \mathrm{sec}$.). F Polished and etched longitudinal section showing the axial zone (right part) and the peripheral zone (left part) $\left(\mathrm{H}_{2} \mathrm{O}_{2} 33 \%\right.$ for 13 days, $\left.20^{\circ} \mathrm{C}\right)$. G Growth layer of the rostrum showing elongated crystallites; unetched sample. H, I Dorsal views of the posterior region of embryonic shell (stages 27-30) showing the absence of the rostrum and wings.

Fig. 9 Fork and ventral process, adult shell (SE-SEM)

A Transverse unetched fracture showing the topographic relationships between the dorsal shield, the fork and the ventral part (septa); IP: inner prismatic layer. B Detailed view of the contact between the septa and the fork. C Unetched fracture showing the lamellar structure of the fork. D Detail of the structure of the lamellae of the fork, with a "prismatic" sublayer (1) and a 
"lamellar" sublayer (2). E Detail of the lamellar structure of the ventral process. F Prismatic structure of the mineralized layer of the ventral process.

Fig. 10 Fourier Transform Infrared spectra of a geological aragonite, proteins (BSA), polysaccharides (chitin), embryonic and adult Sepia shells.

Fig. 11 Raman spectrosopy analysis of Sepia shell showing the presence of aragonite.

A-C Stage 25 embryo. A Circular aperture zone corresponding to the first matrix synthesis site. B Penultimate chamber (with pillars in formation). C Most outer chamber (in formation). D adult shell (dorsal shield).

Fig. S1 Terminology used for the orientation of the fractures and polished sections studied using SEM and AFM.

Fig. S2 Variations in morphology and structure of the chambered zone of adult and embryonic shells.

A Enlargement of the basal part of a pillar of an adult shell; fracture fixed and etched (chromium sulphate $\mathrm{pH} 3.5$ for $4 \mathrm{~h}$.); SE - SEM. B Pillars are covered by an organic membrane (upper part); under the membrane, the granular structure of the pillar is visible; adult sample. SE - SEM. C Etched fracture trough a pillar of an adult shell showing the empty middle part $(\mathrm{NaOH} 0.5 \mathrm{M}$ for 4h at $100^{\circ} \mathrm{C}$, pronase $\mathrm{pH} 7.6$ for $6 \mathrm{~h}$ at $34^{\circ} \mathrm{C}$, chitinase $\mathrm{pH} 5.6$ for $22 \mathrm{~h}$ at $24^{\circ} \mathrm{C}$ ); SE - SEM. D Etched vertical section through the pillar of an adult shell showing the different behaviour of the middle and external parts $\left(\mathrm{NaOH} 1 \mathrm{M}\right.$ for $4 \mathrm{~h} 30$ at $100^{\circ} \mathrm{C}$, then 4 days at $20^{\circ} \mathrm{C}$, lipase $1 \mathrm{mg} / \mathrm{ml}$ pH 9 for $28 \mathrm{~h}$ at $35^{\circ} \mathrm{C}$ ); SE - SEM. E Pillars in the first septa of an adult shell. SE - SEM. F Unetched granular surface of the lateral growing edge of a larval shell; BSE - SEM. G Unetched tangential fracture showing the zig zag "wall" made by coalescent pillars in an adult shell. H-I Stage 25/26 embryonic shell after $24 \mathrm{~h}$ in vitro incubation of the embryo in a calcein-containing sea water (30 mg/L; CNAM, Sigma) followed by $48 \mathrm{~h}$ incubation in sea water, $\mathbf{H}$ Optical image, 
I Fluorescence image showing that calcification occurs during the growth at the distal extremities of the pillars.

Fig. S3 FTIR spectra of the soluble and insoluble organic matrices extracted from the dorsal shield and ventral zone of an adult shell, showing the similarity between the insoluble matrix and the crab chitin.

The dorsal shield and the ventral zone were mechanically separated in adult samples, immersed in $3 \% \mathrm{NaClO}$ for $1 \mathrm{~h}$ to remove organic contaminants, rinsed with Milli-Q water, dried, and ground into powder by grinding with an electric mortar for $10 \mathrm{~min}$ to obtain homogeneous granulometry. Powdered samples were immersed in Milli-Q water and decalcified by progressive addition of 50\% acetic acid so that the $\mathrm{pH}$ (automatically controlled with a titrimeter) is above 4 . The entire extract was centrifuged at $21,000 \mathrm{~g}$ for $15 \mathrm{~min}$, which separated the supernatant (soluble) and precipitated (insoluble) fractions. The soluble fraction was desalted by exchange with Milli-Q water on a Microconcentrator (Filtron) using a 3-kDa cut-off membrane and lyophilized. Powdered samples and $\mathrm{KBr}$ were oven-dried at $38^{\circ} \mathrm{C}$ overnight. Then, they were mixed (about 5\% powdered samples in $\mathrm{KBr}$ ) and loaded into the sample cup. 


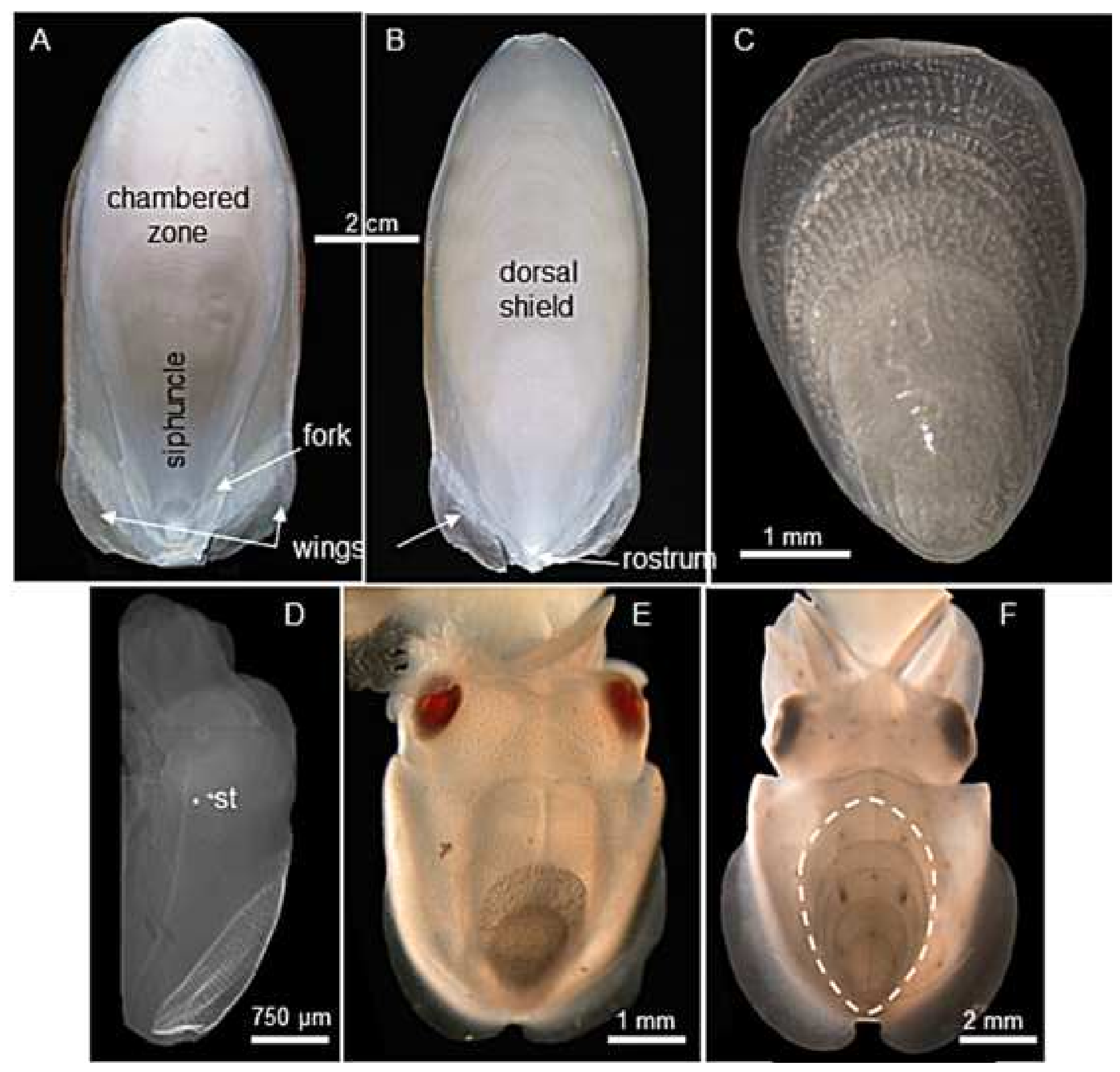




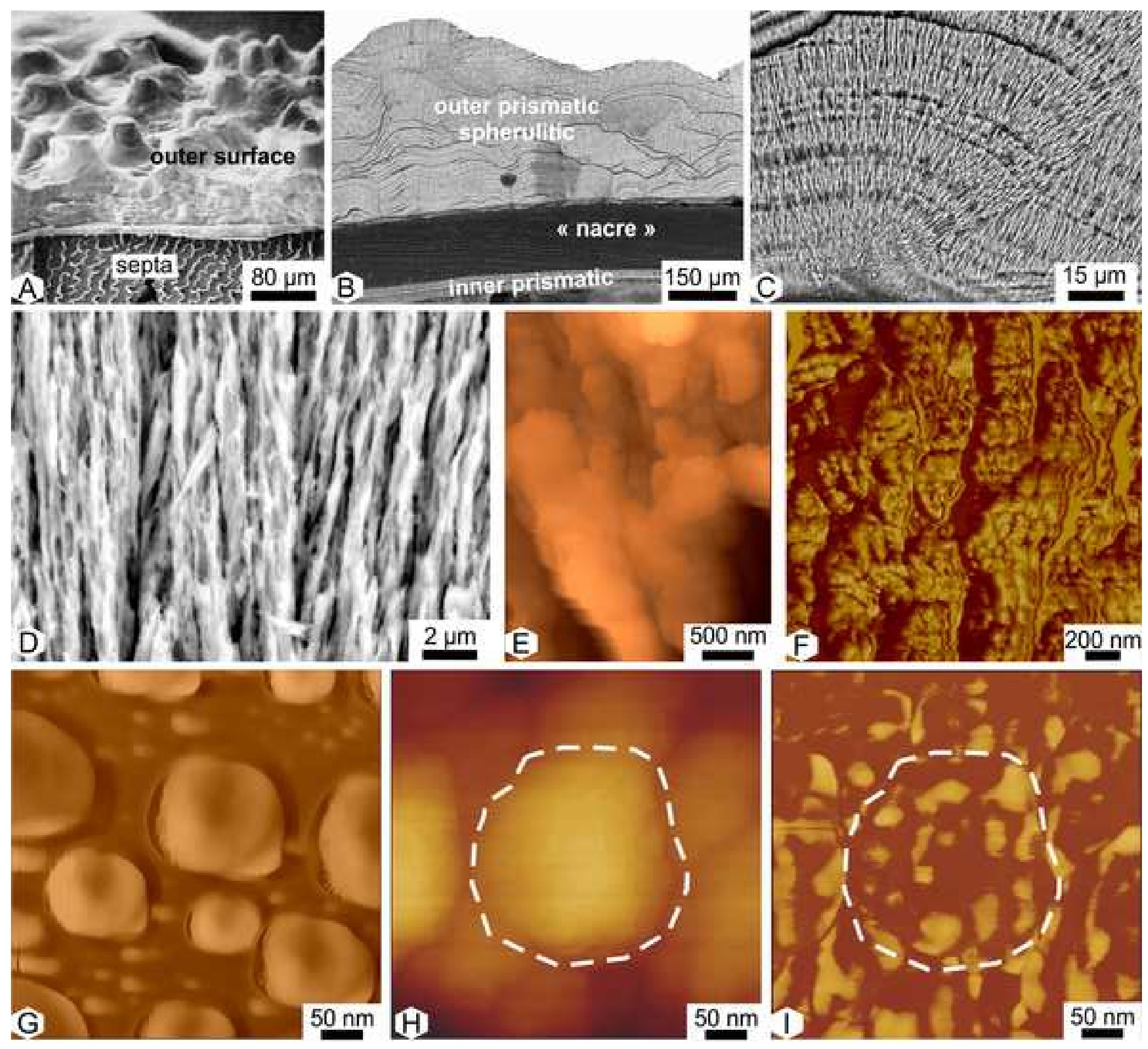




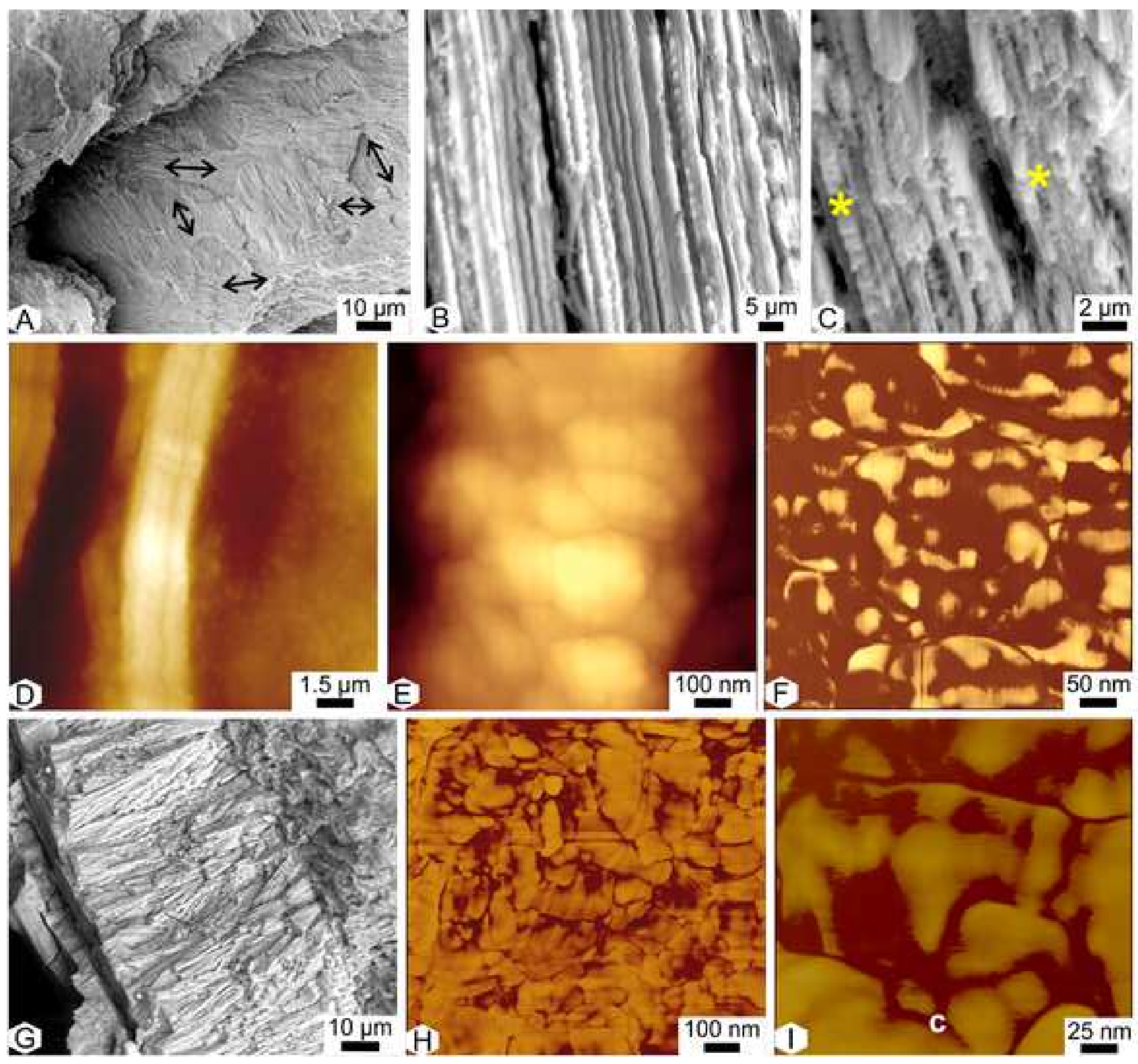



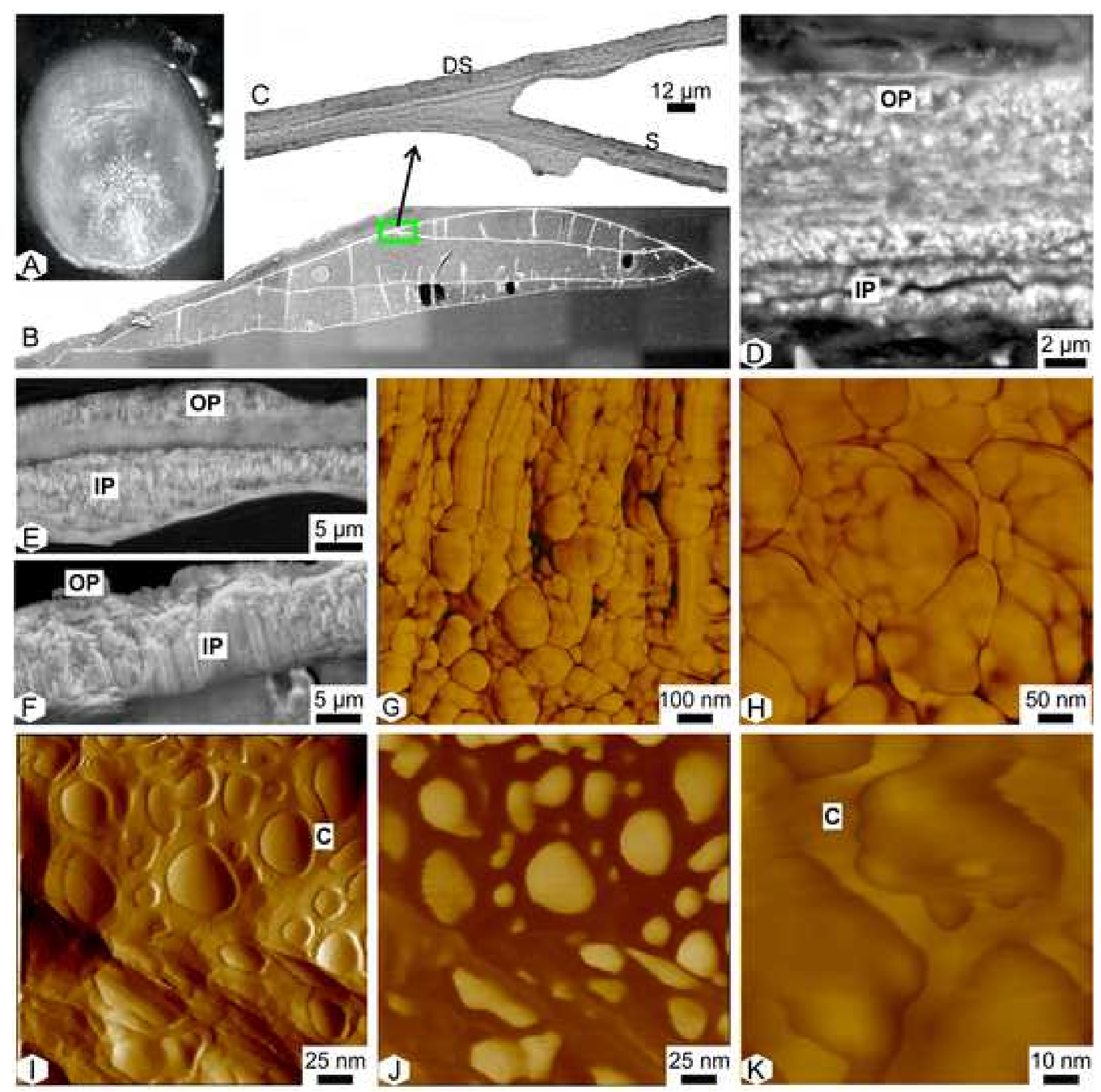

C

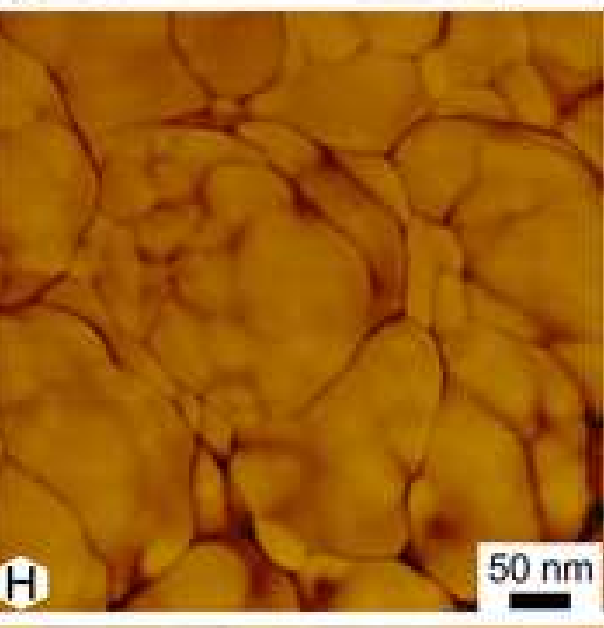



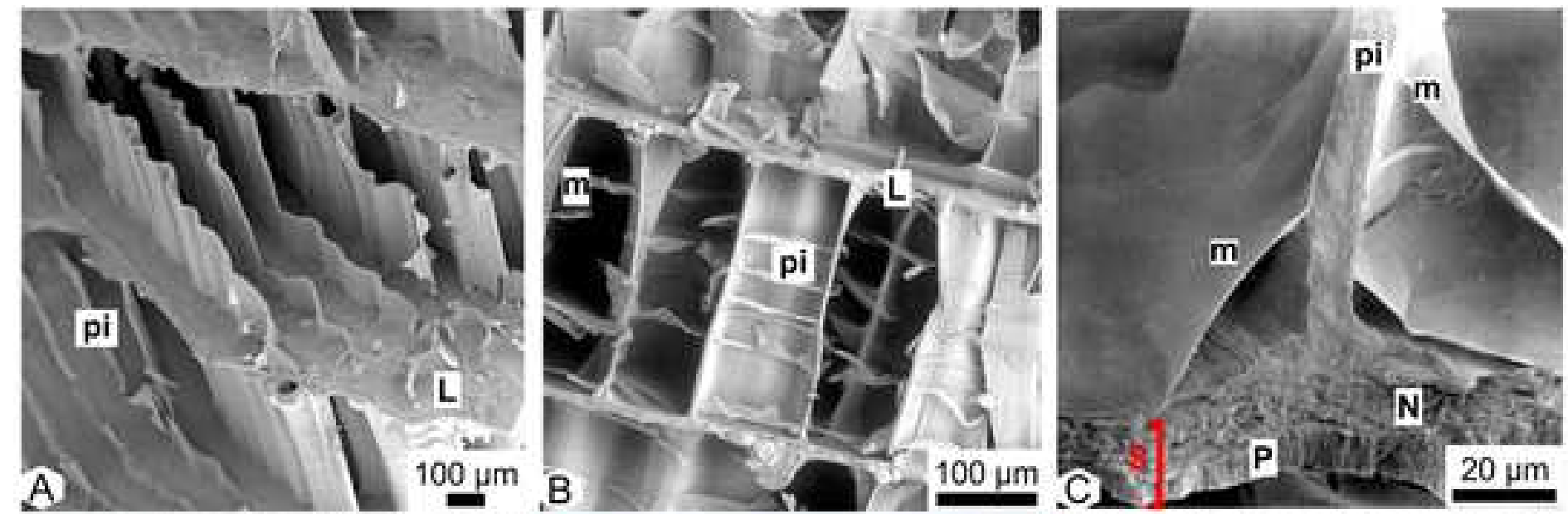

A

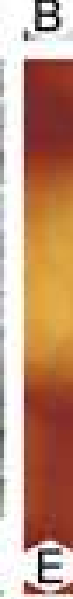

C. P P N $20 \mu \mathrm{m}$
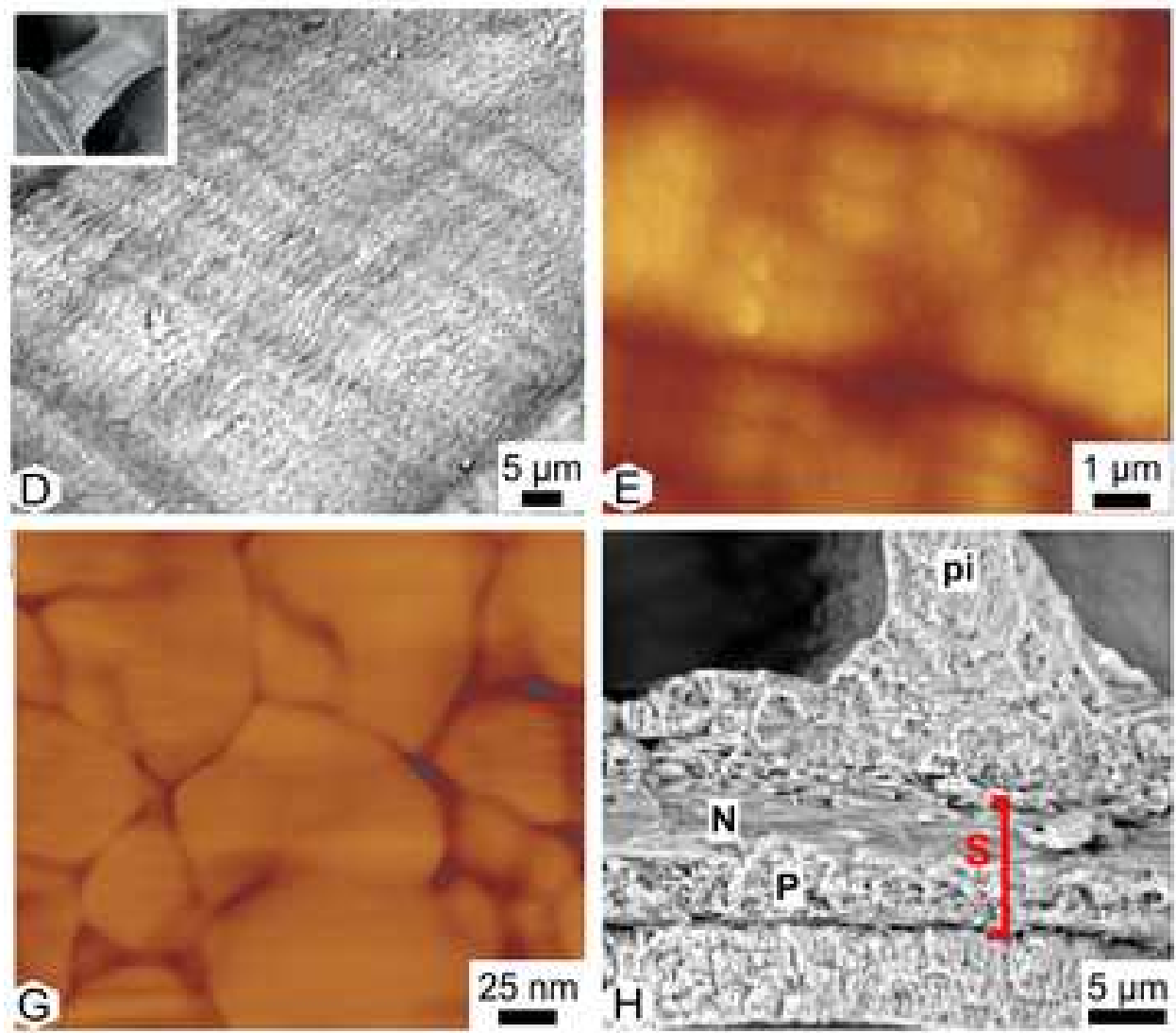

1.

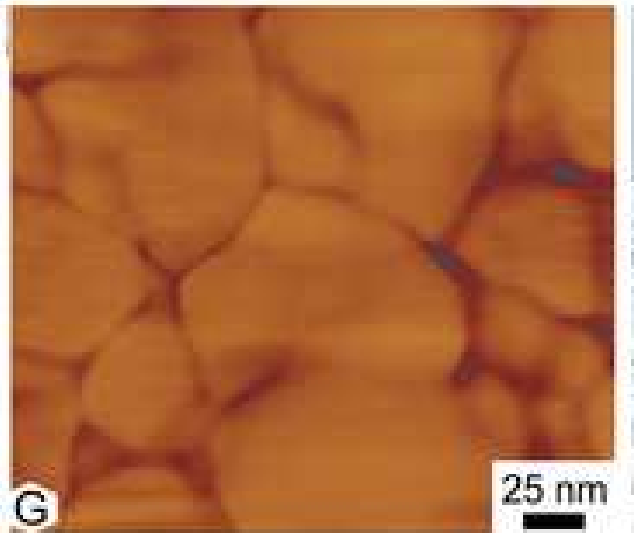

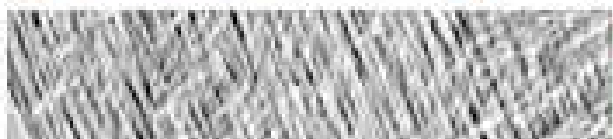
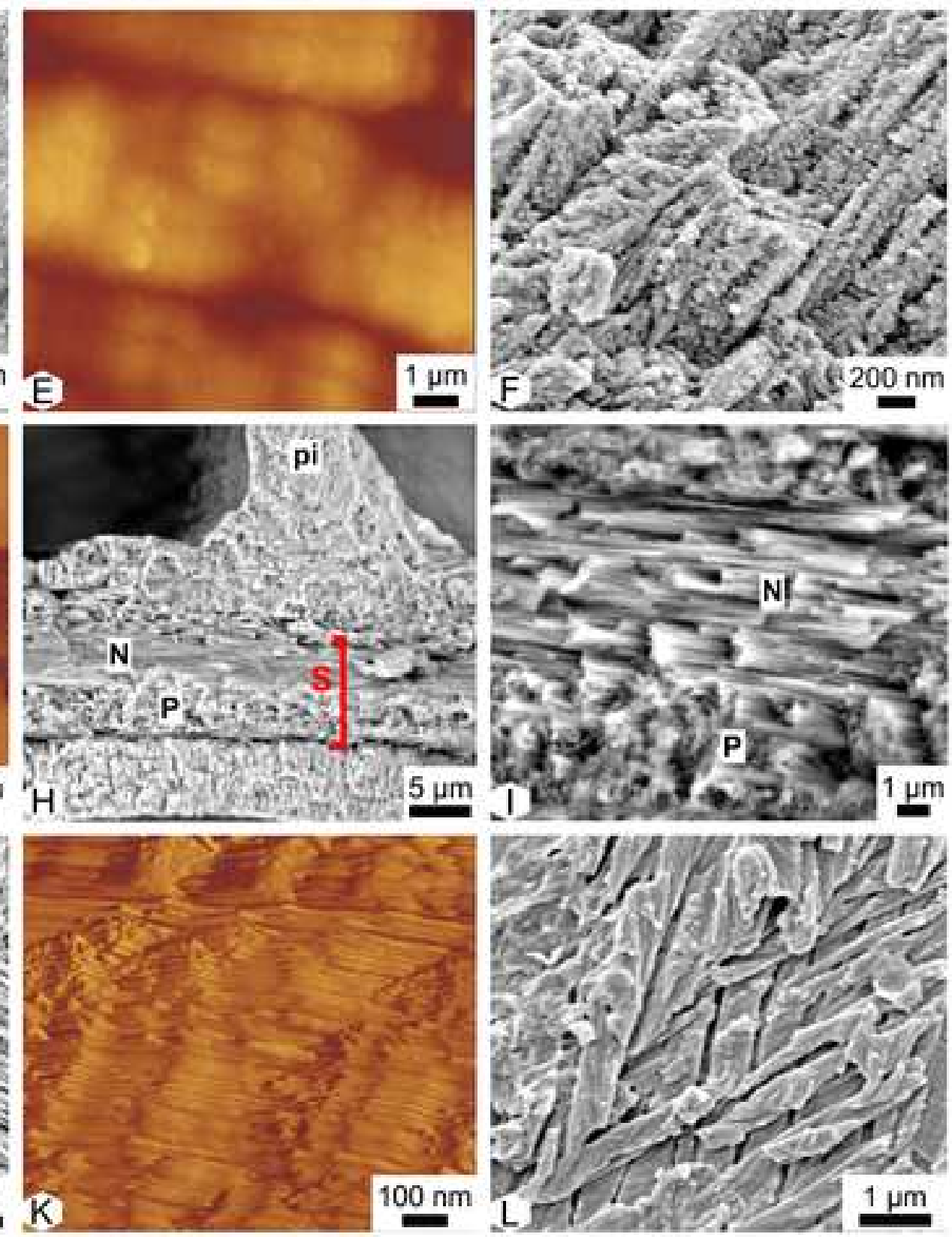

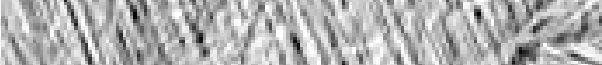

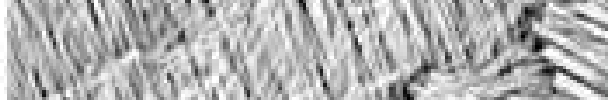
in
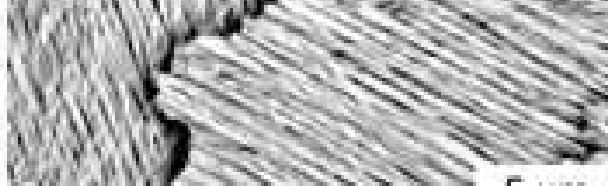
Jis $5 \mu \mathrm{m}$

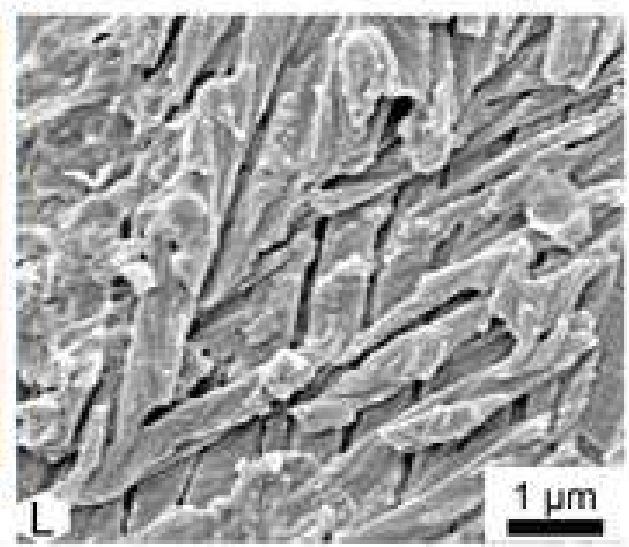



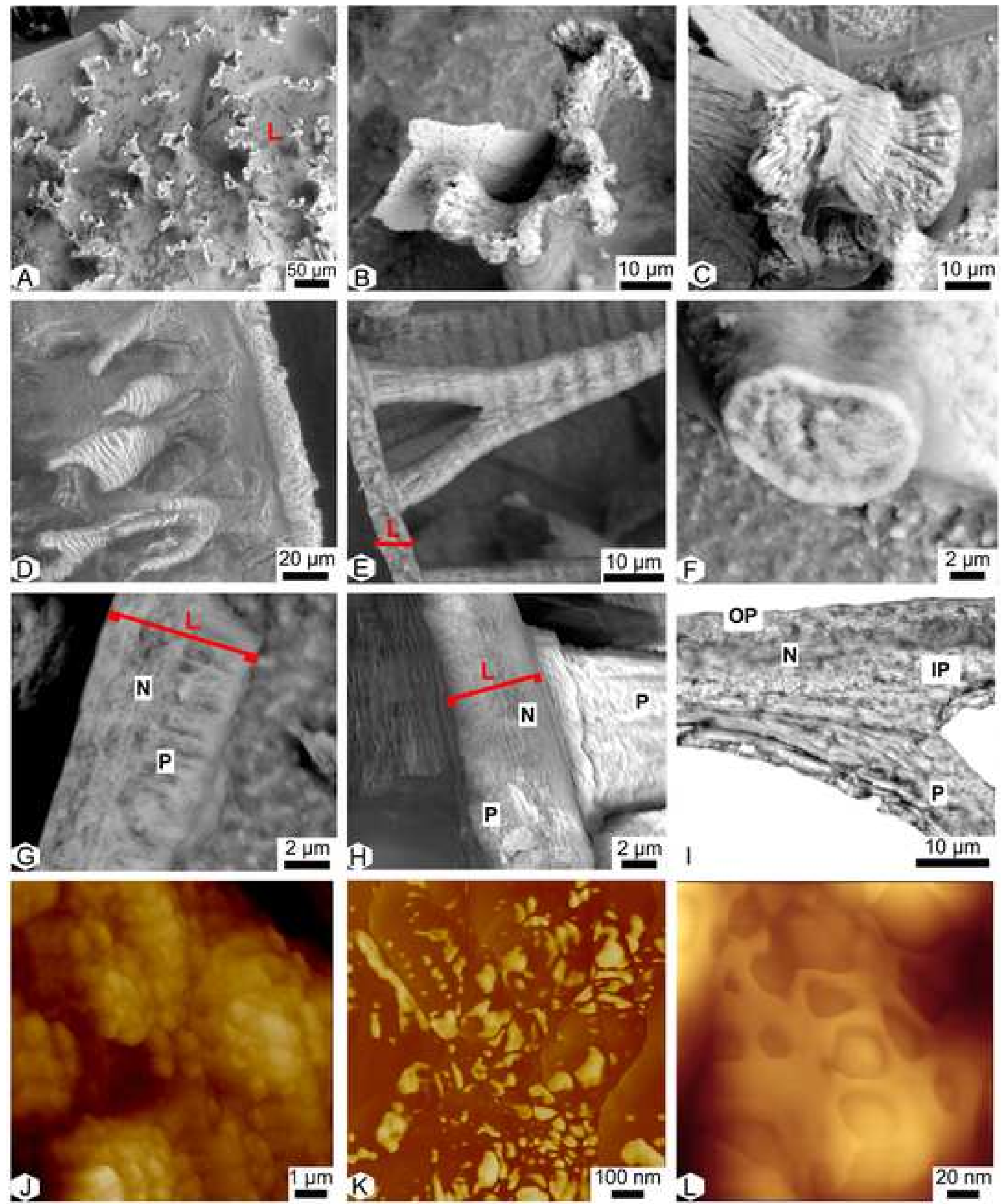

K atcis $8=100 \mathrm{~nm}$

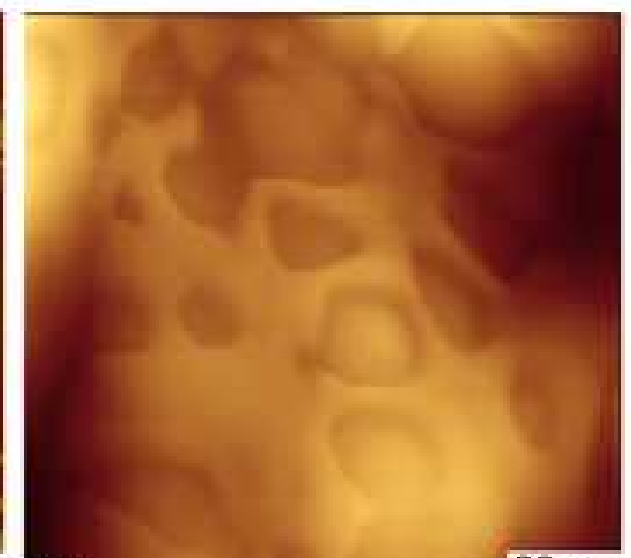

L 

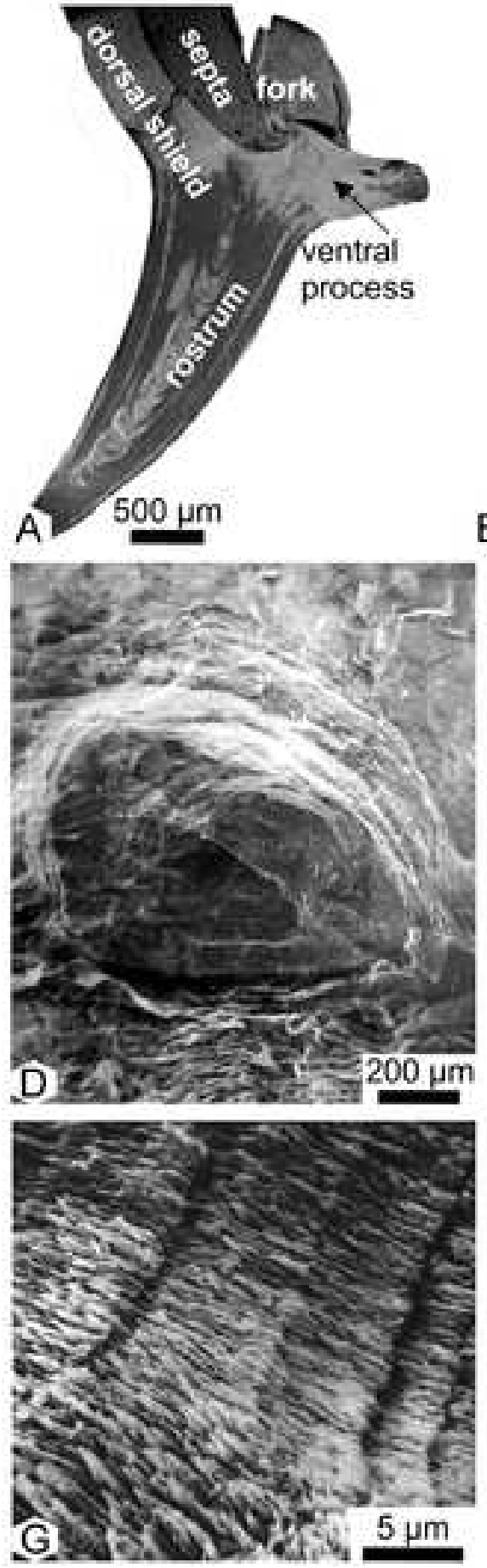
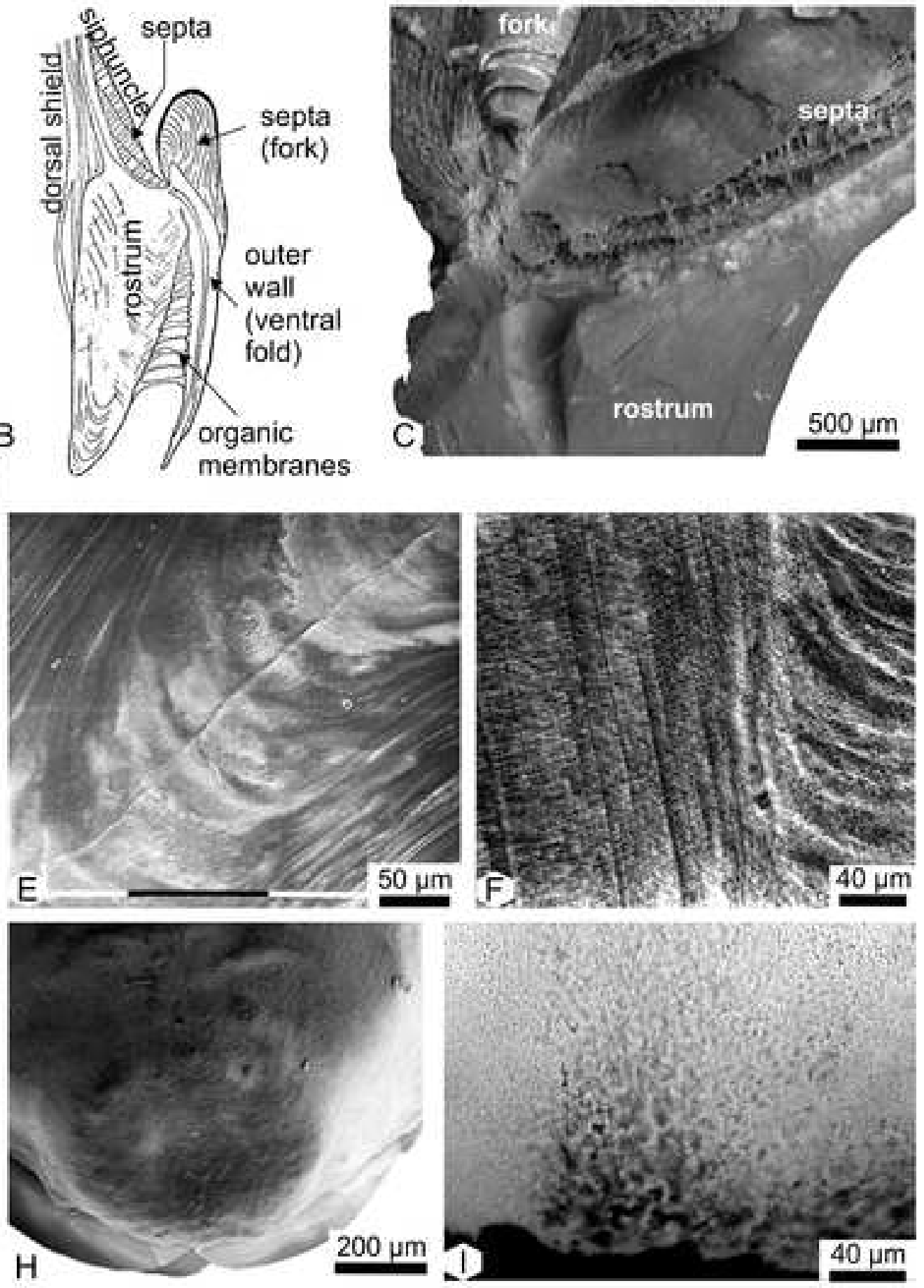


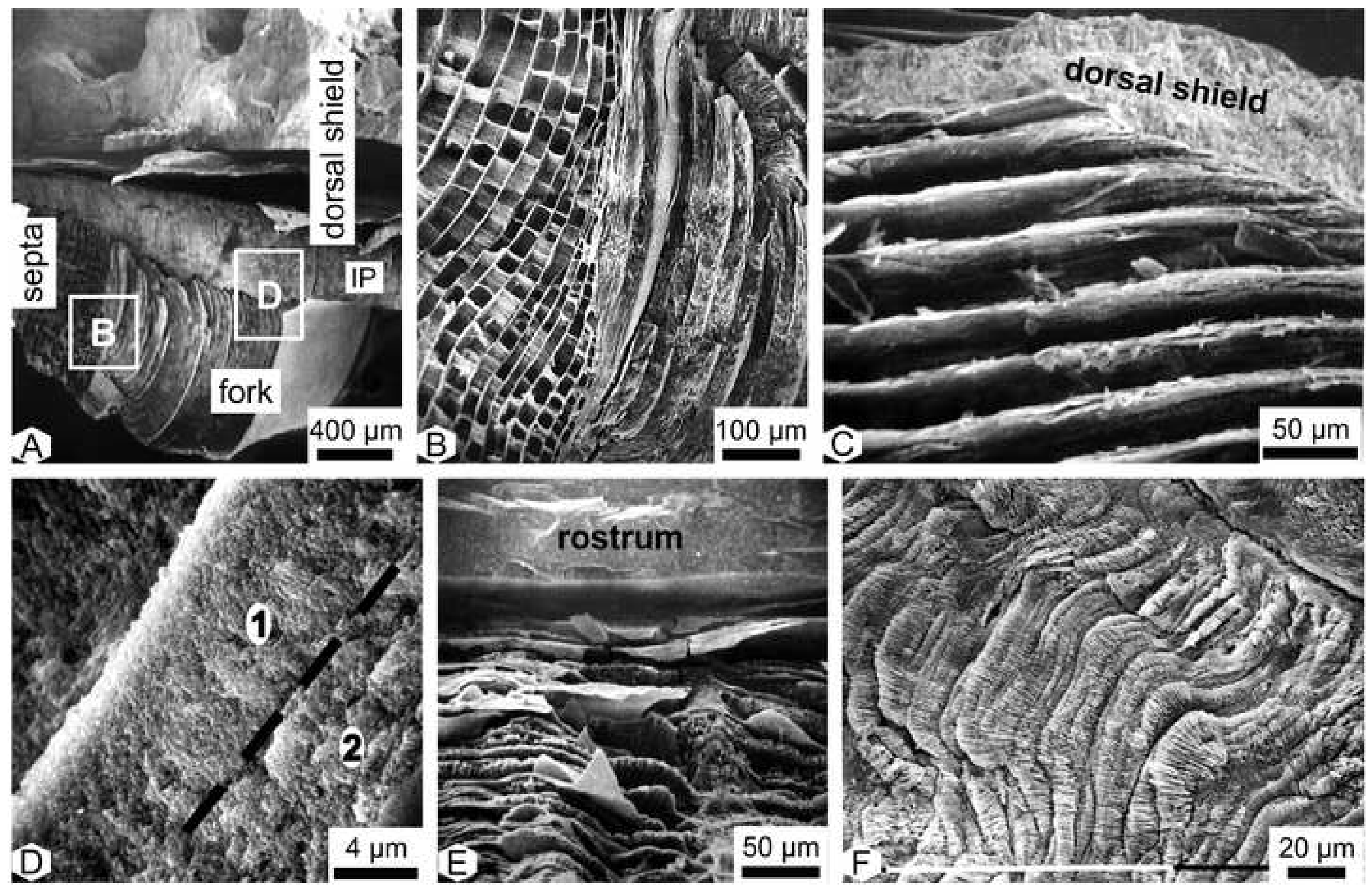




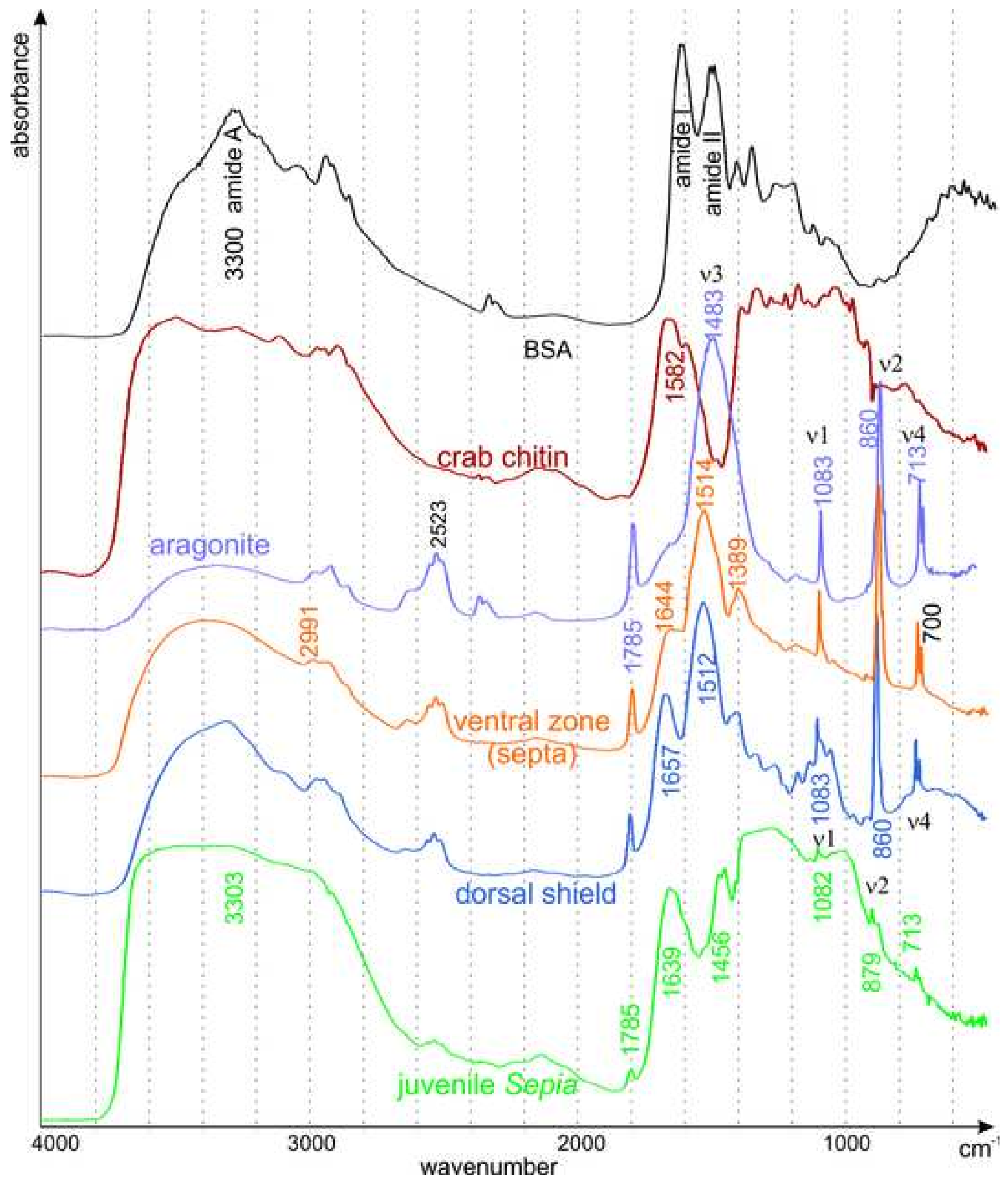




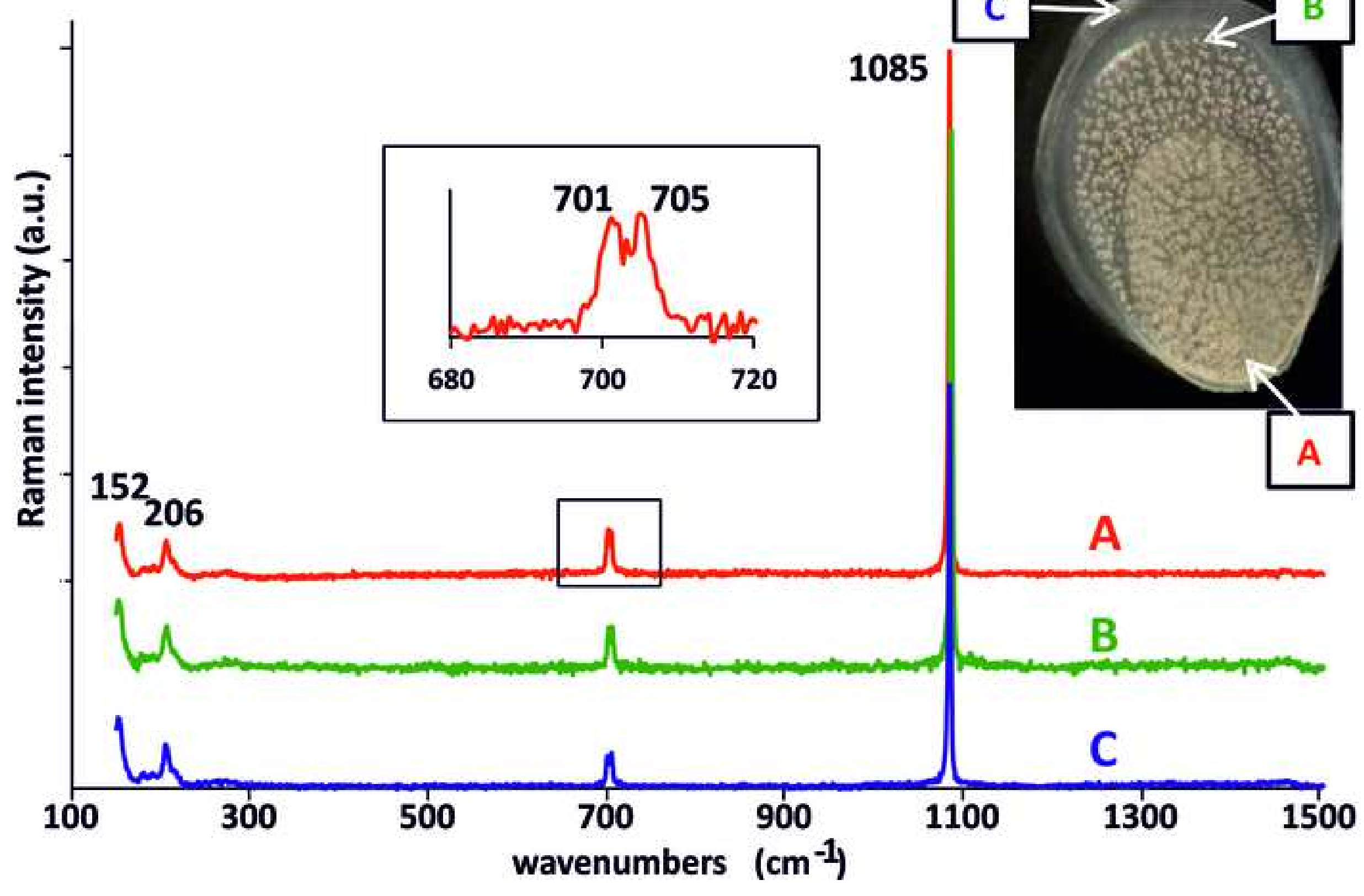




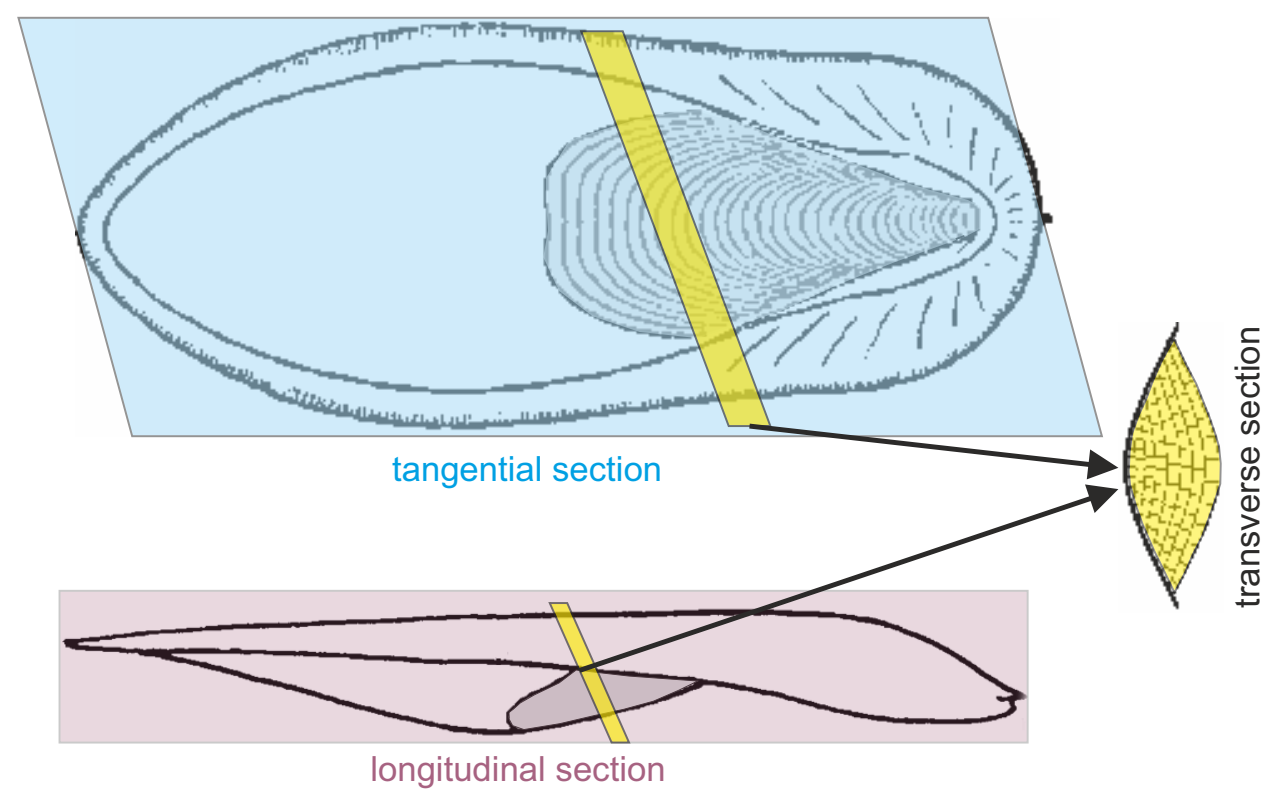

figure S1 


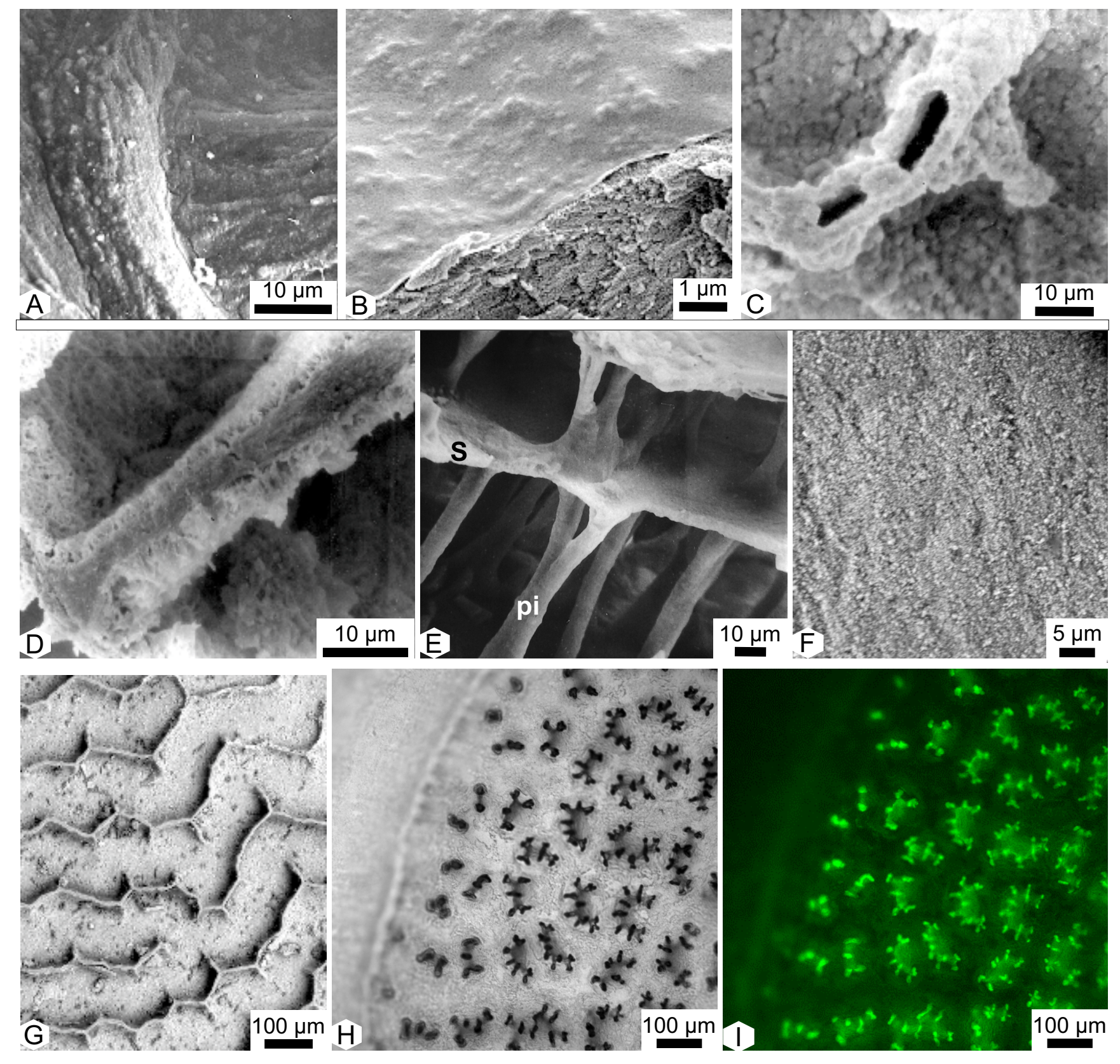

\section{figure S2}



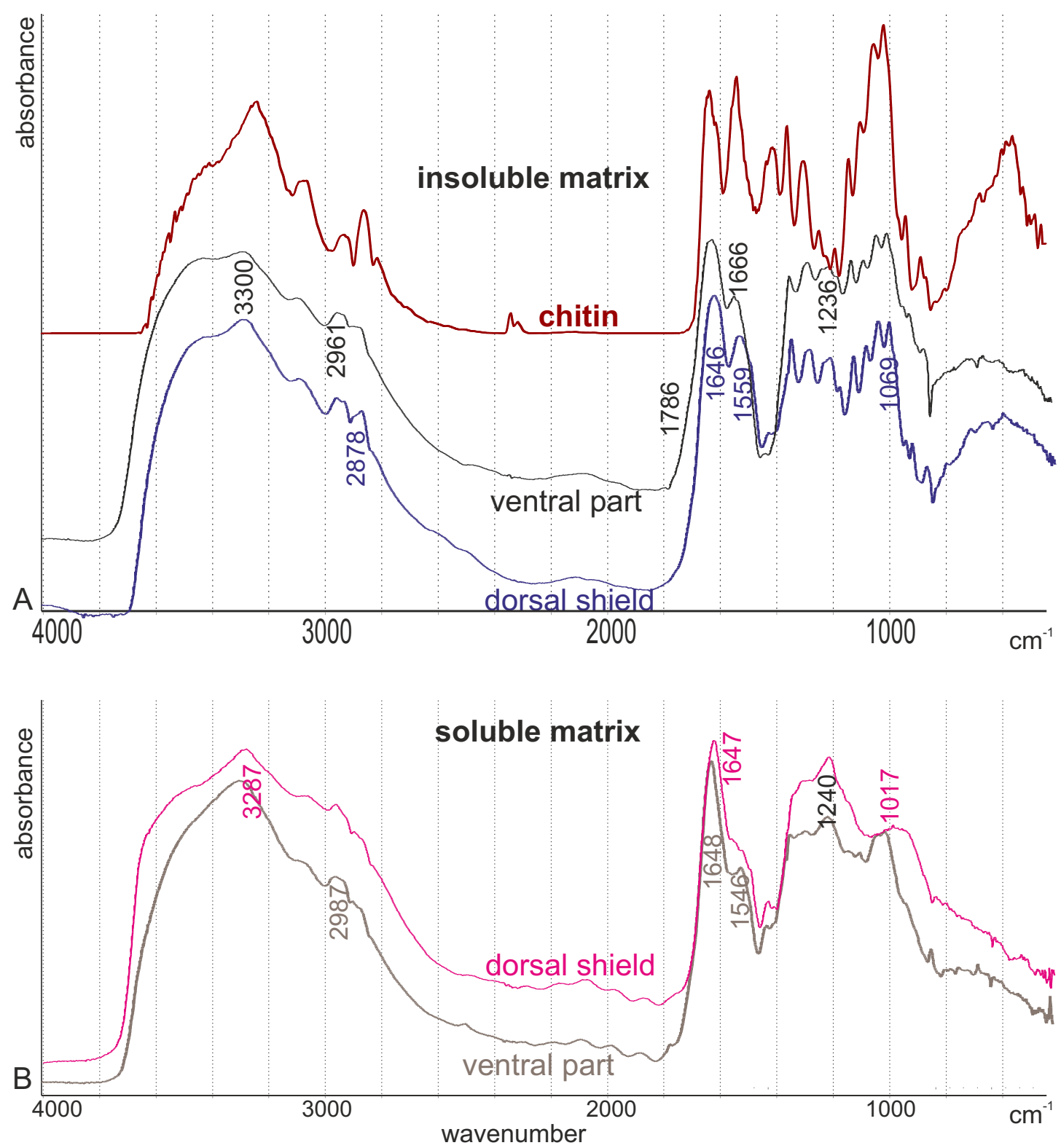

figure S3 